McNeill, L.C., Dugan, B., Petronotis, K.E., and the Expedition 362 Scientists Proceedings of the International Ocean Discovery Program Volume 362

publications.iodp.org

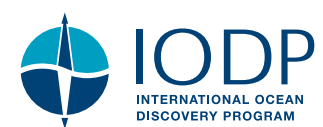

\title{
Contents
}

\section{Expedition 362 summary $^{1}$}

L.C. McNeill, B. Dugan, K.E. Petronotis, J. Backman, S. Bourlange, F. Chemale, W. Chen, T.A. Colson, M.C.G. Frederik, G. Guèrin, M. Hamahashi, T. Henstock, B.M. House, A. Hüpers, T.N. Jeppson, S. Kachovich, A.R. Kenigsberg, M. Kuranaga, S. Kutterolf, K.L. Milliken, F.L. Mitchison, H. Mukoyoshi, N. Nair, S. Owari, K.T. Pickering, H.F.A. Pouderoux, S. Yehua, I. Song, M.E. Torres, P. Vannucchi, P.J. Vrolijk, T. Yang, and X. Zhao ${ }^{2}$

Keywords: International Ocean Discovery Program, IODP, JOIDES Resolution, Expedition 362, Site U1480, Site U1481, Sumatra, Sumatra subduction zone, Sunda subduction zone, Andaman-Nicobar Islands, Wharton Basin, Indo-Australian plate, Bengal Fan, Nicobar Fan, Himalaya, Ninetyeast Ridge, Sumatra-Andaman 2004 earthquake, shallow seismogenic slip, décollement, megathrust, tsunami, forearc, Neogene, late Miocene, Late Cretaceous, subduction input sediment, diagenesis, sediment gravity flow, pelagic, oceanic crust, volcanic ash, mud, clay, silt, sand, siliciclastic, calcareous ooze, chalk

\section{Abstract}

Drilling the input materials of the north Sumatran subduction zone, part of the $5000 \mathrm{~km}$ long Sunda subduction zone system and the origin of the $\mathrm{Mw} \sim 9.2$ earthquake and tsunami that devastated coastal communities around the Indian Ocean in 2004, was designed to groundtruth the material properties causing unexpectedly shallow seismogenic slip and a distinctive forearc prism structure. The intriguing seismogenic behavior and forearc structure are not well explained by existing models or by relationships observed at margins where seismogenic slip typically occurs farther landward. The input materials of the north Sumatran subduction zone are a distinctively thick (as thick as $4-5 \mathrm{~km}$ ) succession of primarily Bengal-Nicobar Fan-related sediments. The correspondence between the 2004 rupture location and the overlying prism plateau, as well as evidence for a strengthened input section, suggest the input materials are key to driving the distinctive slip behavior and long-term forearc structure. During Expedition 362, two sites on the Indian oceanic plate $\sim 250 \mathrm{~km}$ southwest of the subduction zone, Sites U1480 and U1481, were drilled, cored, and logged to a maximum depth of 1500 meters below seafloor. The succession of sediment/rocks that will develop into the plate boundary detachment and will drive growth of the forearc were sampled, and their progressive mechanical, frictional, and hydrogeological property evolution will be analyzed through postcruise experimental and modeling studies. The large penetration depths with good core recovery and successful wireline logging in the challenging submarine fan materials will enable evaluation of the role of thick sedimentary subduction zone input sections in driving shallow slip and amplifying earthquake and tsunami magnitudes at the Sunda subduction zone and globally at other subduction zones where submarine faninfluenced sections are being subducted.

\section{Introduction}

On 26 December 2004, an Mw 9.2 earthquake struck Sumatra and the Andaman-Nicobar Islands (e.g., Lay et al., 2005) (Figure F1). The resulting tsunami inundated coastal communities around the Indian Ocean, killing more than 250,000 people. The high-moment release, southern 2004 rupture region was centered beneath an unusually wide $(\sim 150 \mathrm{~km})$ forearc plateau, representing the surface of the modern accretionary wedge bounded by steep slopes (e.g., Moore et al., 1980; Henstock et al., 2006; Fisher et al., 2007). The plateau and its width contrast with the wedge structure of many other accretionary margins. The December 2004 earthquake was followed by the Mw 8.7 Nias earthquake in March 2005 (e.g., Hsu et al., 2006; Briggs et al., 2006) and by others in 2007 (e.g., Konca et al., 2008) and 2010 (Newman et al., 2011) on the margin. These earthquakes all ruptured megathrust sections between the Indo-Australian and Burma-Sunda plates (Figures F1, F2). The 2004 and 2005 events were the first great earthquakes to be analyzed using advanced seismological and geodetic techniques and the first of a series of global $\mathrm{Mw} \sim 9$ earthquakes forcing reevaluation of subduction earthquake models. In 2012, a sequence of large-magni-

\footnotetext{
${ }^{1}$ McNeill, L.C., Dugan, B., Petronotis, K.E., Backman, J., Bourlange, S., Chemale, F., Chen, W., Colson, T.A., Frederik, M.C.G., Guèrin, G., Hamahashi, M., Henstock, T., House, B.M., Hüpers, A., Jeppson, T.N., Kachovich, S., Kenigsberg, A.R., Kuranaga, M., Kutterolf, S., Milliken, K.L., Mitchison, F.L., Mukoyoshi, H., Nair, N., Owari, S., Pickering, K.T., Pouderoux, H.F.A., Yehua, S., Song, I., Torres, M.E., Vannucchi, P., Vrolijk, P.J., Yang, T., and Zhao, X., 2017. Expedition 362 summary. In McNeill, L.C., Dugan, B., Petronotis, K.E., and the Expedition 362 Scientists, Sumatra Subduction Zone. Proceedings of the International Ocean Discovery Program, 362: College Station, TX (International Ocean Discovery Program). https://doi.org/10.14379/iodp.proc.362.101.2017

2 Expedition 362 Scientists' addresses.

MS 362-101: Published 6 October 2017

This work is distributed under the Creative Commons Attribution 4.0 International (CC BY 4.0) license. (cc)BY
} 
Figure F1. Example coseismic rupture models of the 2004 Sumatra-Andaman earthquake using combinations of seismic, geodetic, and tsunami data. A. Coseismic and $\sim 30$ day postseismic slip, with slip offshore North Sumatra concentrated beneath the forearc high. Contours = depth of subducting plate. B. Waveform and GPS inversion suggesting substantial shallow slip (although postseismic transients may be included). C. Model based on tsunami observations that shows significant slip on shallow plate boundary.

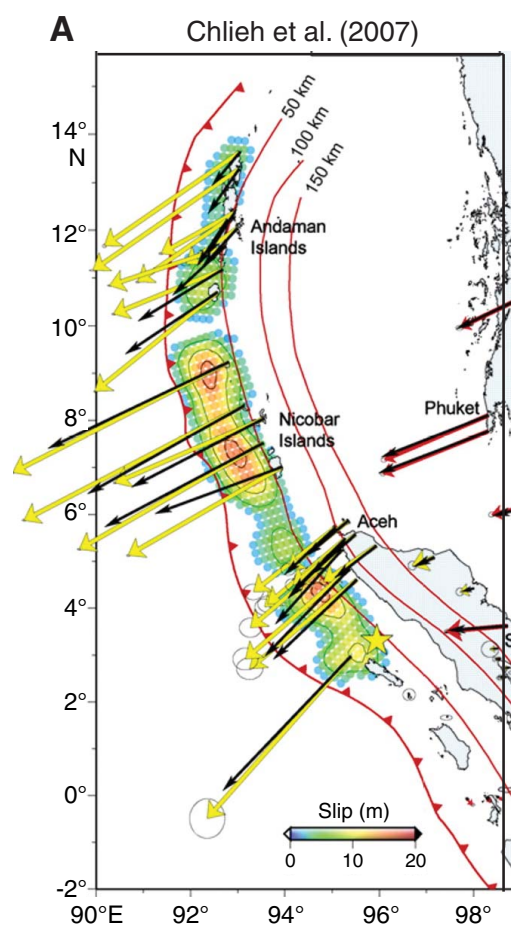

B Rhie et al. (2007)

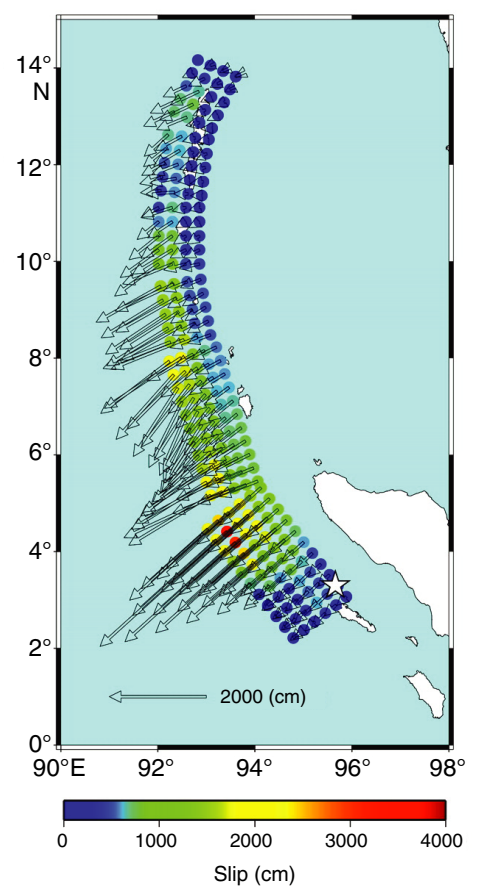

C Fujii and Satake (2007)

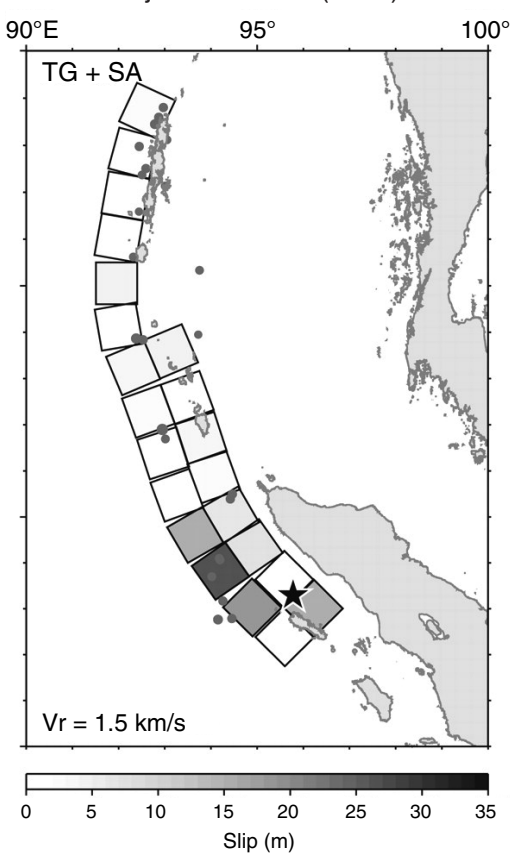

Figure F2. Tectonic setting of the Sumatran subduction zone showing major recent and historic plate boundary earthquake ruptures and their magnitudes (from Meltzner et al., 2012, and references therein). Black lines = faults, gray lines = fracture zones.

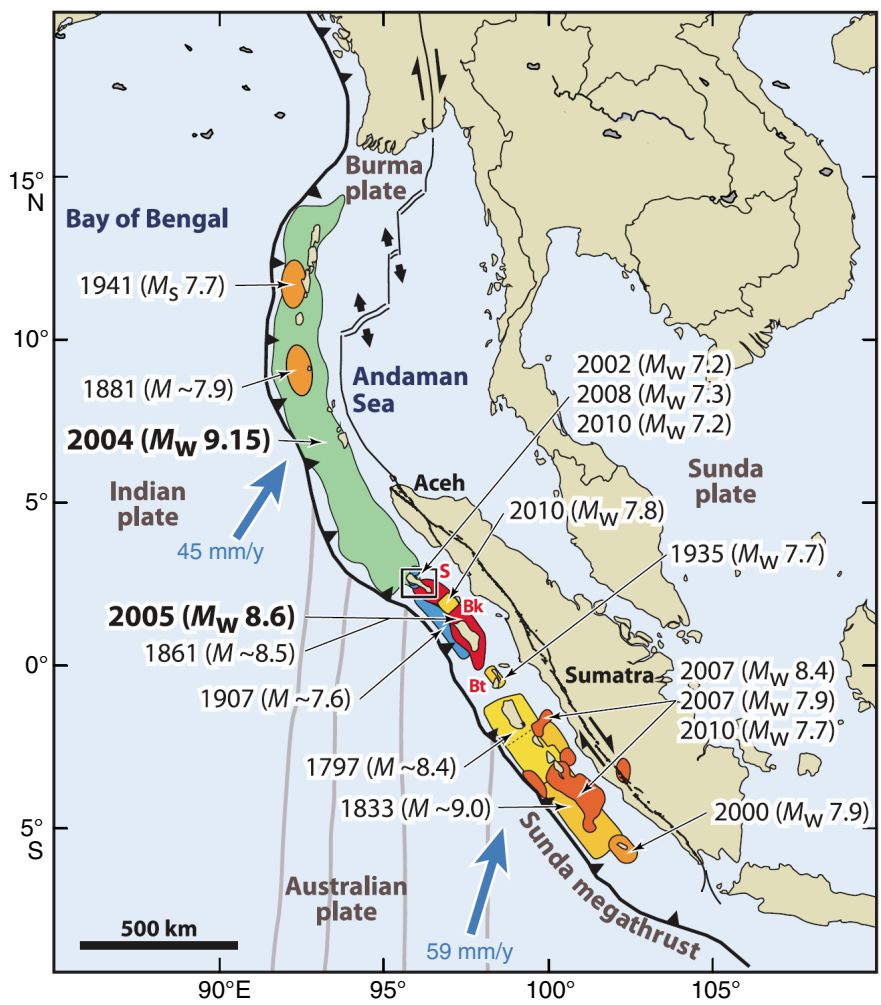


tude oceanic plate earthquakes (including Mw 8.2 and 8.6) ruptured basement west of the 2004 rupture zone (e.g., Wei et al., 2013; Carton et al., 2014). The 2004 earthquake, followed by the 2011 Tohoku-Oki earthquake ( $\mathrm{Mw} 9$ ), both showed unexpectedly large magnitudes and shallow seismogenic slip beneath the prism that extended potentially out to the trench (e.g., Fujiwara et al., 2011; Bleterey et al., 2016).

The focus of drilling during International Ocean Discovery Program (IODP) Expedition 362 was within the oceanic plate offshore the north Sumatran forearc (Figures F3, F4). The sedimentary succession on the 60-70 Ma basaltic crust of the oceanic plate comprises a basal pelagic layer overlain by sediments of the Nicobar Fan. This succession may be comparable to some other subduction margins, but here the sediments are thicker (as thick as $4-5 \mathrm{~km}$ at the deformation front offshore North Sumatra), are thought to have accumulated over a long time period from the Himalayan collision zone in contrast to the Cascadia and Alaska margins with large influxes of Quaternary sediment transported across the forearc (lat- eral input) onto the oceanic/subducting plate, and are expected to be in thermal equilibrium. The Sunda margin is therefore likely to have physical and mechanical properties different from other studied input sections, such as Nankai, Japan, Costa Rica, and Cascadia, but is of direct relevance to several other undersampled thickly sedimented subduction margins with limited earthquake records and unknown hazard potential (e.g., the southern Lesser Antilles and the Makran).

The central aim of Expedition 362 was to collect core and log data of the incoming oceanic plate section to help understand the nature of seismogenesis in North Sumatra, with a longer term goal of understanding seismogenic processes on related margins. This drilling project collected samples and data required to investigate how input materials drive shallow seismogenic slip and influence forearc morphology. The ultimate goal is to understand hazard potential for this margin and eventually others with similar strength behavior and morphology.

Figure F3. Regional physiography of the eastern Indian Ocean with existing drill sites (orange squares), including Expedition 362 Sites U1480 and U1481 (red circles). The Nicobar Fan is located between the Ninetyeast Ridge and the Sunda subduction zone.

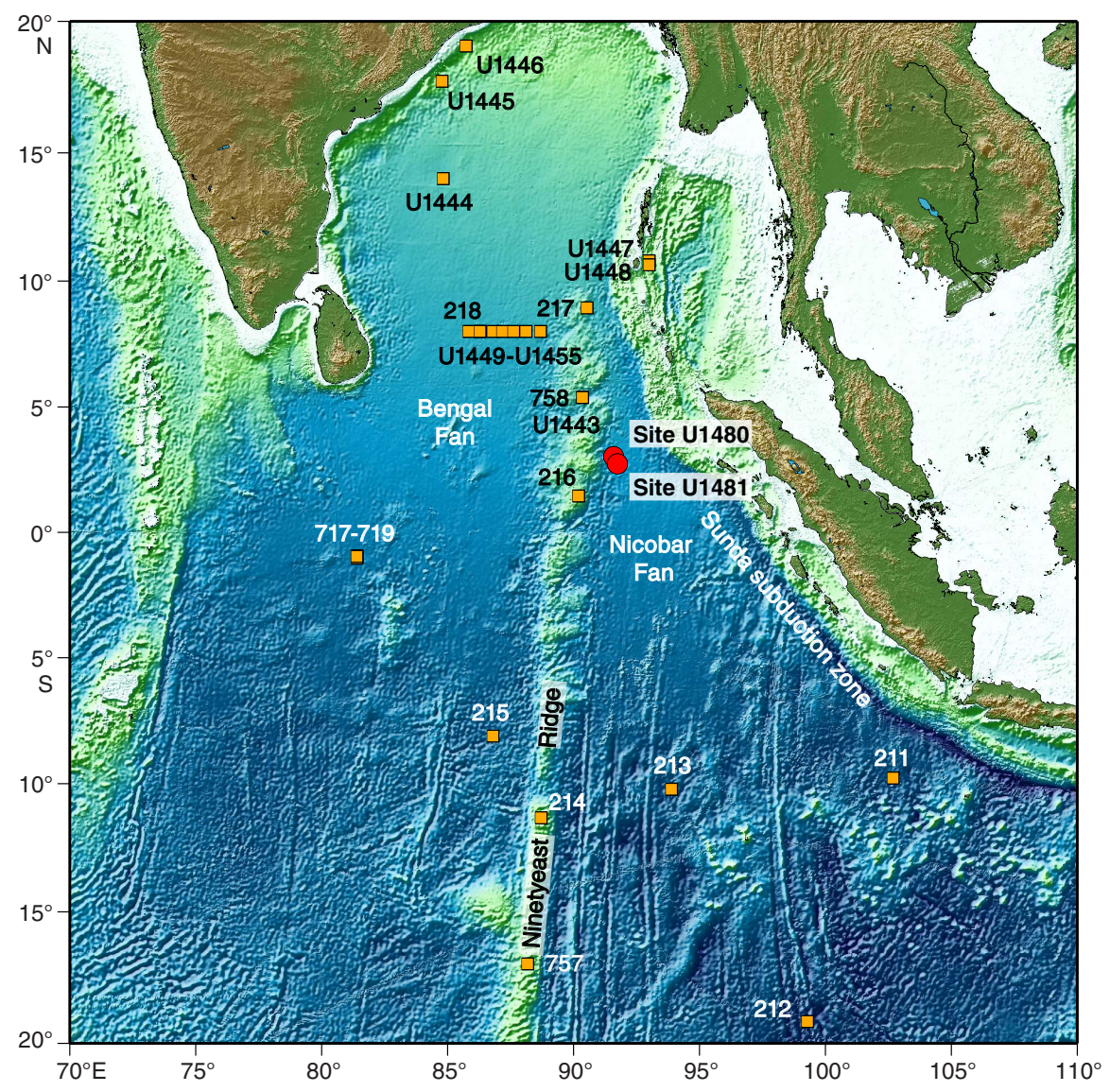


Figure F4. Recently collected multichannel seismic reflection profiles (black dashed lines) and existing earlier profiles (gray dotted lines) across the north Sumatran forearc (location of the southern 2004 earthquake rupture zone) and Indian oceanic plate overlain on multibeam bathymetry. Gray circles $=$ seismicity. Inset: seismicity and focal mechanisms associated with the December 2004 and March 2005 earthquake ruptures. Red circles = Expedition 362 drill sites

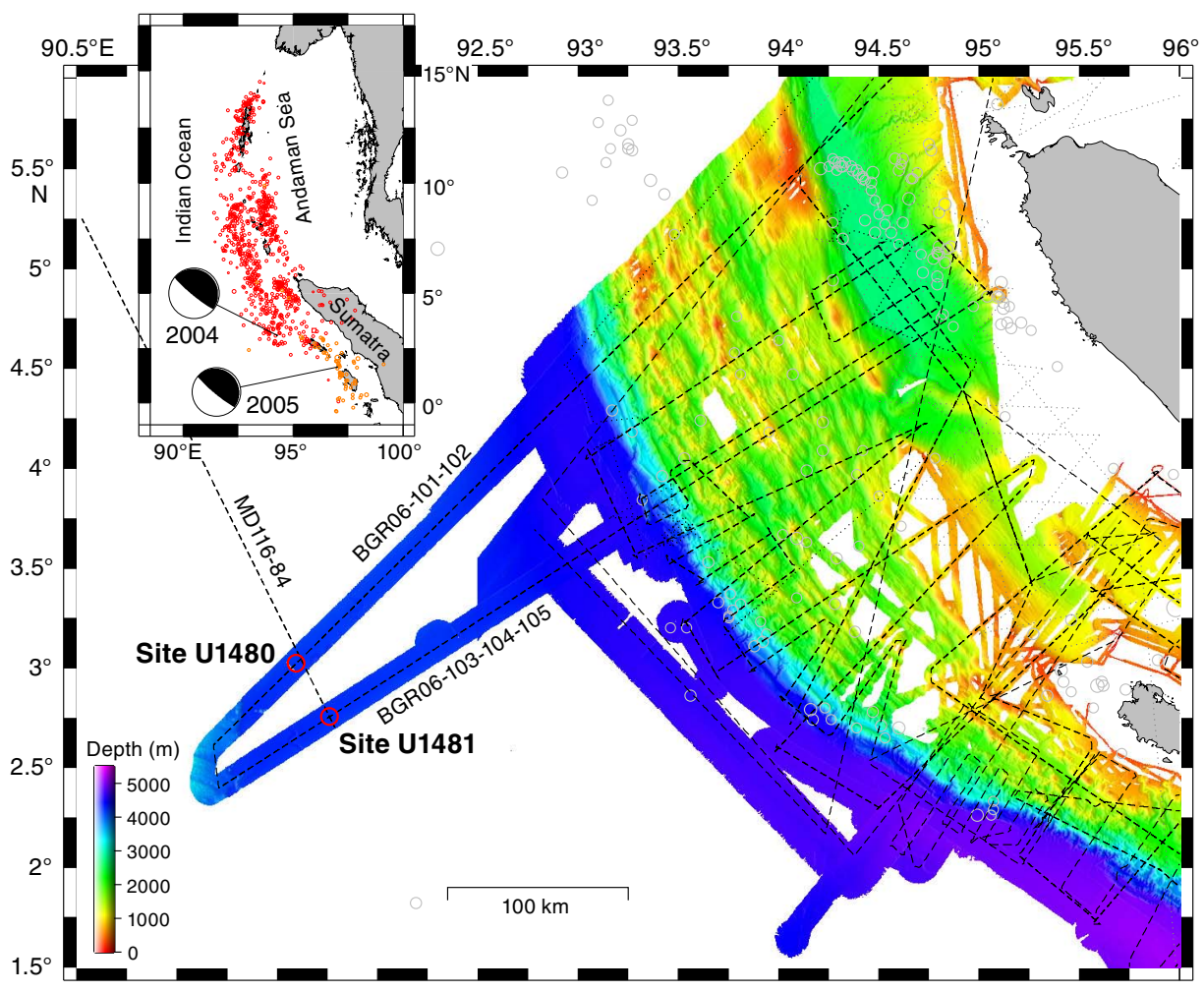

\section{Scientific objectives}

The primary objectives of Expedition 362 were to establish (1) the initial and evolving properties of the north Sumatran incoming sedimentary section and (2) the potential effect of these properties on seismogenesis, tsunamigenesis, and forearc development for comparison with global examples. To address these objectives, two riserless drill sites (U1480 and U1481; Figures F4, F5) were drilled to sample and log the oceanic plate input succession of the southern portion of the 2004 earthquake rupture zone. The succession is composed of the distal part of the trench wedge, the Bengal-Nicobar Fan succession, the prefan pelagic succession, and the top of basaltic basement (Figures F6, F7). Combined operations at the sites were planned to sample the complete sedimentary succession, sediment/basement interface, and oceanic crustal basalt. The two sites were designed to test for local variations in stratigraphy, lithology, physical properties, thermal state, and fluid geochemistry at two neighboring but different locations. The sedimentary succession includes lithologic horizons that may develop into the plate boundary décollement for the north Sumatran margin. The primary candidates are (1) a horizon within the deepest sediments overlying oceanic basement (Seismic Horizon C; Figures F6, F7, F8, F9) that develops into a high-amplitude, negative-polarity reflector closer to the trench, which is interpreted as a weak, high-porosity, and probably fluid-rich layer (Dean et al., 2010), and (2) a horizon within the deeper fan sediments (Cook, 2014). In other parts of the margin, such as offshore Central Sumatra (Cook et al., 2014), the sediment/basement interface acts as the décollement, and this interface may become important as a detachment surface at greater depth within the subduction zone, including offshore North Sumatra. In addition, the internal and basal properties of the north Sumatran
Figure F5. Bathymetric map of region around Sites U1480 and U1481. Note the meandering channel running approximately north-south and fault scarps trending northeast and northwest (linear color anomalies).

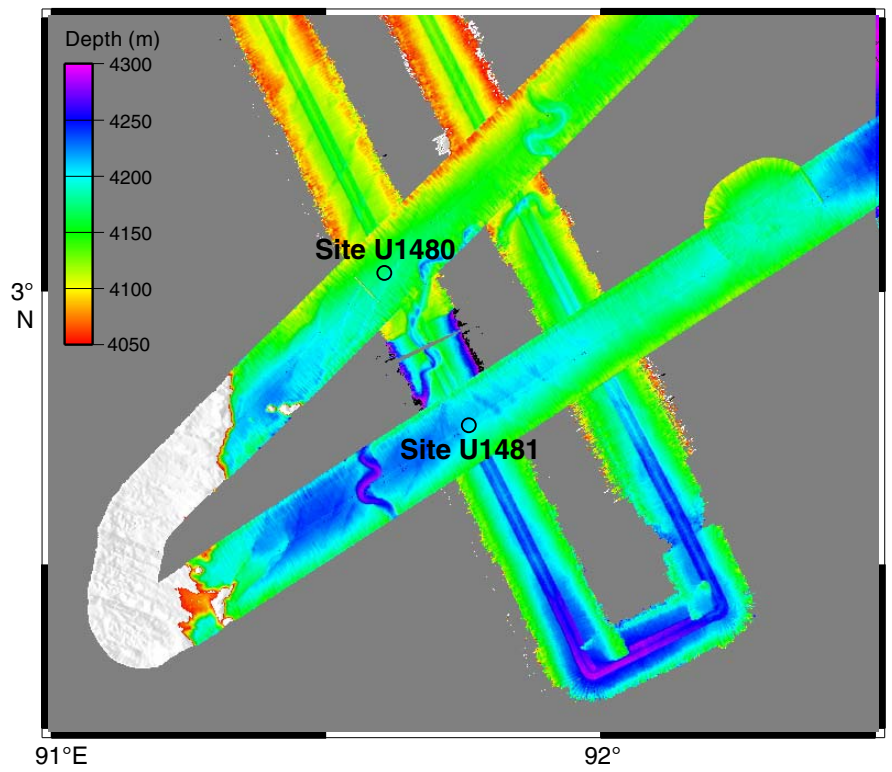

forearc are thought to drive the unusually wide prism plateau and the landward vergence of outer prism thrust faults (e.g., McNeill and Henstock, 2014; Fisher et al., 2007; Gaedicke et al., 2006). Postcruise experimental analyses and numerical models will be used to extrapolate the input section properties-constrained by core samples and logging data-to the higher stresses and temperatures that 
Figure F6. Seismic Profiles BGR06-101 and BGR06-102 across the Indian oceanic plate west of the Sunda subduction zone, North Sumatra, from the Ninetyeast Ridge to the deformation front, with Site U1480. Seismic Horizon A (blue line) is the unconformable boundary between the trench wedge and the underlying Nicobar fan sediments. Seismic Horizon B (green line) is the transition from reflective to less reflective stratigraphy. Seismic Horizon C (dashed red line) is the high-amplitude reflector having negative polarity toward the subduction zone and is identified as a potential décollement horizon by Dean et al. (2010). Seismic Horizon D is oceanic basement. See Figure F4 for profile locations. See McNeill et al. (2016) for source and details of site survey seismic reflection data.

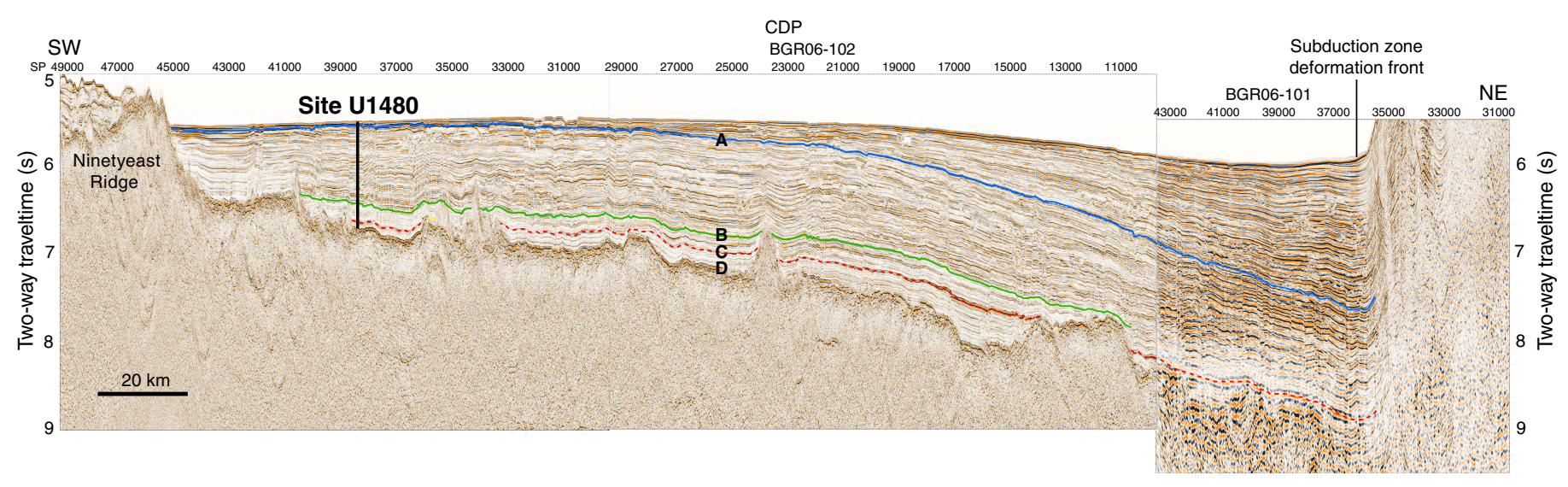

Figure F7. Seismic Profiles BGR06-103, BGR06-104, and BGR06-105 across the Indian oceanic plate west of the Sunda subduction zone, North Sumatra, from the Ninetyeast Ridge to the deformation front, with Site U1481. Seismic Horizon A (blue line) is the unconformable boundary between the trench wedge and the underlying Nicobar fan sediments. Seismic Horizon $B^{*}$ (green line) is the transition downsection from reflective to less reflective stratigraphy. The line is dashed where transition is less distinct. Seismic Horizon C (dashed red line) is the high-amplitude reflector having negative polarity toward the subduction zone and is identified as a potential décollement horizon by Dean et al. (2010). Seismic Horizon D is oceanic basement. See Figure F4 for profile locations. See McNeill et al. (2016) for source and details of site survey seismic reflection data.

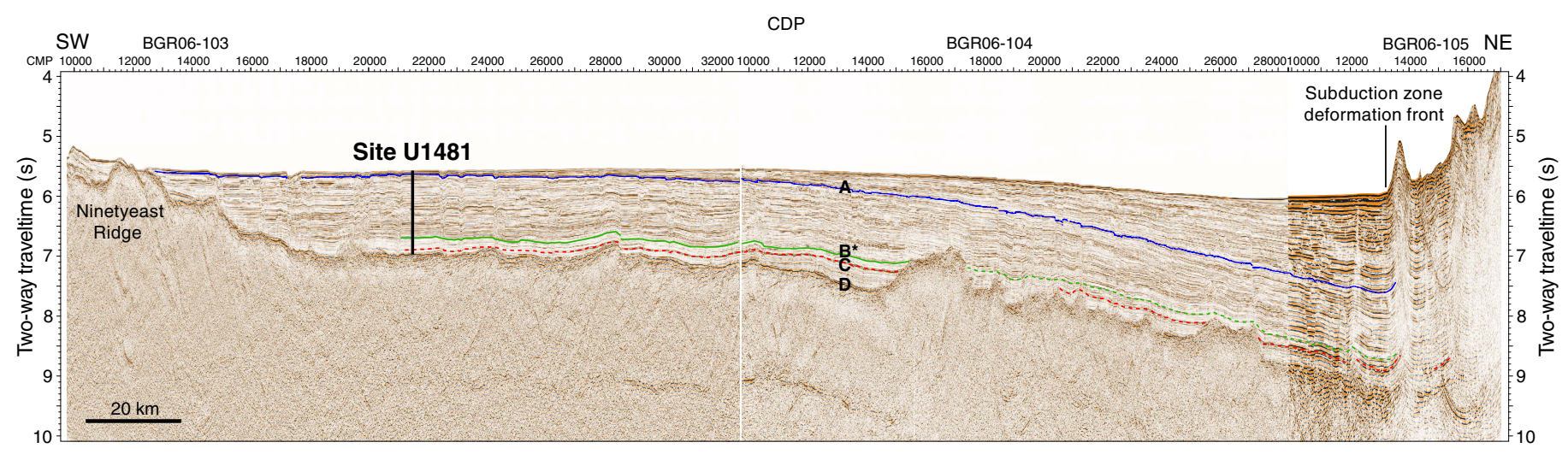

these materials would experience during burial and subduction through time. We anticipate that the increased pressure and temperature contribute to diagenetic processes that create a strong prism core and promote shallow seismogenic slip. See McNeill et al. (2016) for full details.

\section{Primary objectives}

1. To determine the lithology, sedimentation rates, and physical, chemical, and thermal properties of the input section, and to determine how temporal changes in sedimentation rate and lithology influence the physical properties of the section.

Changes in sedimentation rate, lithology, and physical and thermal properties of the sediments are influenced by sediment source and supply, including the Bengal-Nicobar Fan system, and in turn are controlled by local and regional tectonics and climate. These parameters then influence the growth of the prism through time and the physical properties of the prism interior and base, with the latter influencing décollement properties.
2. To assess compaction, induration, and diagenetic state of the deep input sediments that eventually form the interior and base of the accretionary prism and develop into the décollement.

These states will advance as the input section thickens and is accreted. Strengthening of the sedimentary section would contribute to a strong prism core and promote shallow seismogenic slip. Onboard results will be complemented by a series of postcruise experimental and numerical analyses to evaluate how these states evolve along varying temperature and pressure paths.

3. To determine similarities and any distinct differences in lithology and physical properties within the stratigraphic section, in particular between the Bengal-Nicobar Fan sediments and the more slowly deposited pelagic sediments.

Strong contrasts downsection or weak intervals (layers or boundaries) may promote décollement/detachment development, which is potentially important for both plate boundary fault formation and the evolution of the forearc prism. 
Figure F8. Seismic reflection Profile BGR06-102 at Site U1480 with primary seismic Horizons A-D interpreted prior to Expedition 362 . See Figure F6 for details. See McNeill et al. (2016) for source and details of site survey seismic reflection data.

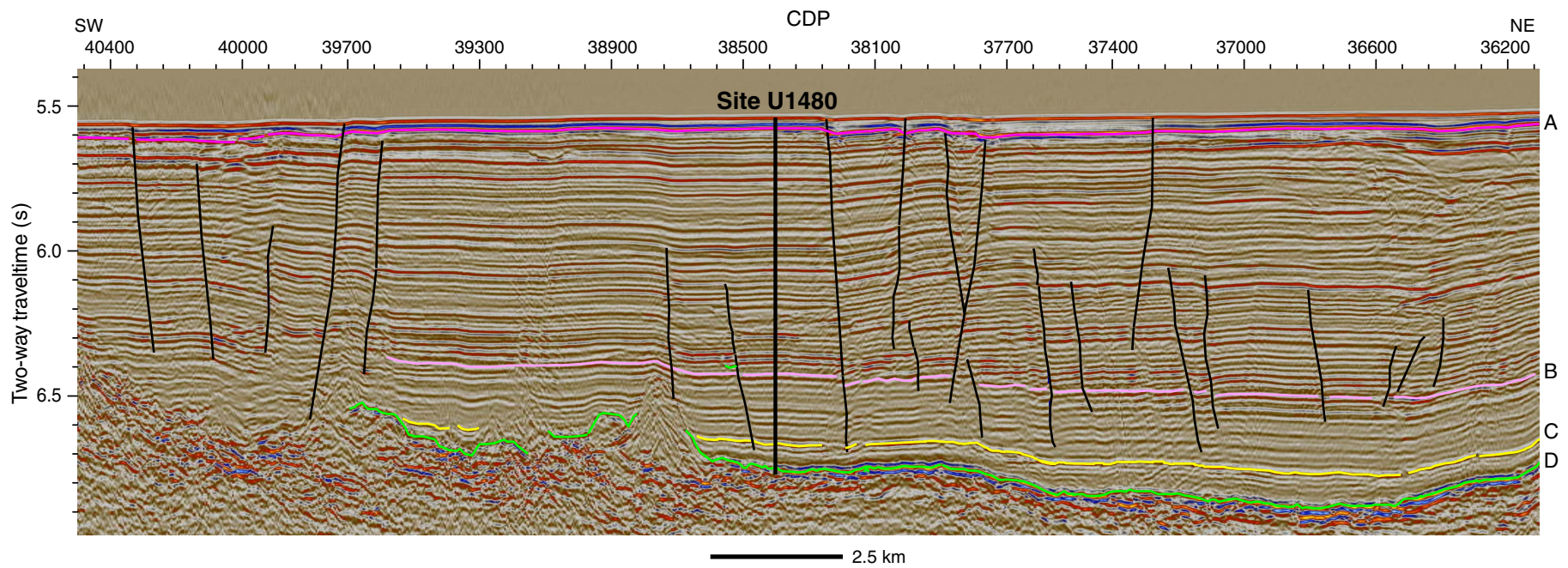

Figure F9. Seismic reflection Profile BGR06-103 at Site U1481 with primary seismic Horizons A-D interpreted prior to and during Expedition 362 . See Figure F7 for details. Note that seismic Horizon B correlates to Horizon B on Profile BGR06-102 (Site U1480), but Horizon B* marks the change from reflective to less reflective stratigraphy on Profile BGR06-103 (Site U1481), deeper stratigraphically than on Profile BGR06-102. See McNeill et al. (2016) for source and details of site survey seismic reflection data.

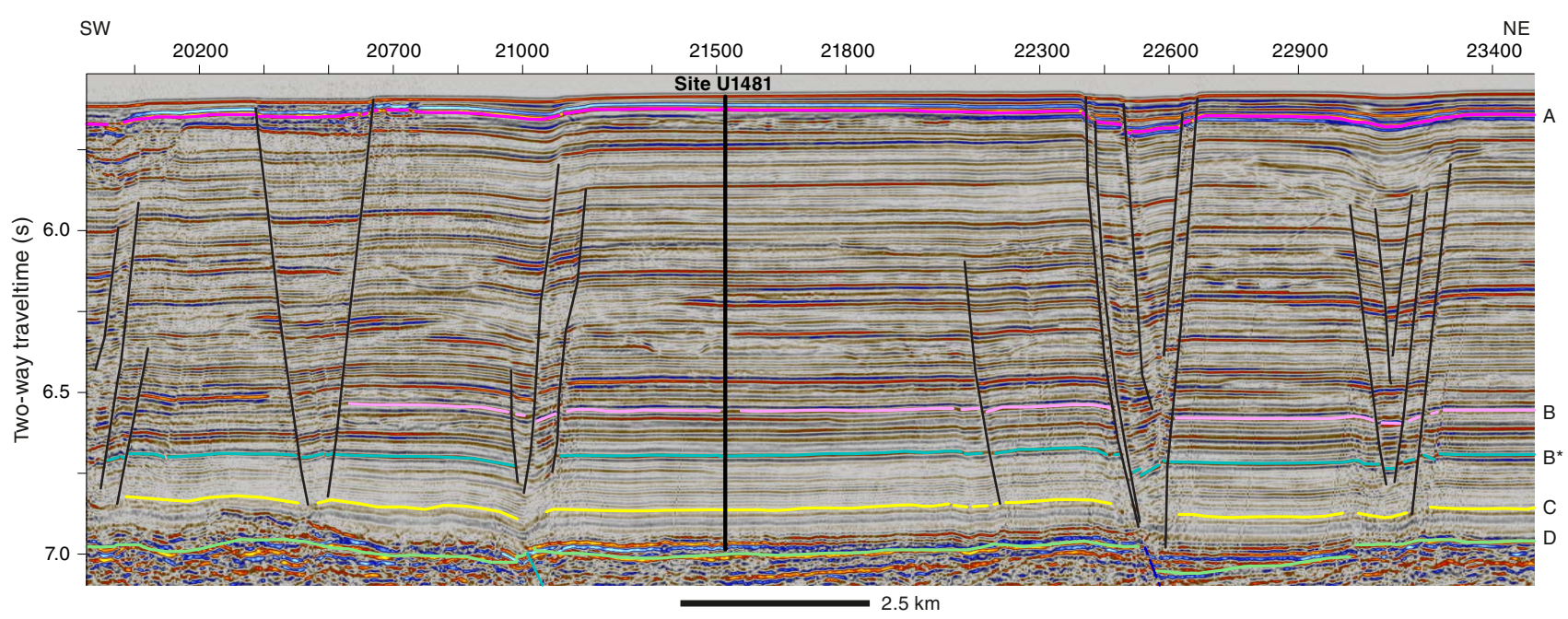

\section{Secondary objectives}

1. To evaluate the state of stress in the oceanic plate and the interactions between regional deformation processes.

The Indo-Australian plate deforms in response to a wide range of processes, including Sumatran subduction, India-Eurasia collision, plate flexure, and oceanic plate fault reactivation. The latter includes fracture zone reactivation and a series of complex largemagnitude earthquakes that occurred in 2012 (e.g., Delescluse et al., 2012).

2. To expand eastern Indian Ocean records of paleoclimate and regional tectonics using the history of sediment supply to the Neogene Nicobar Fan within the Bengal-Nicobar Fan system in order to assess possible temporal changes in monsoonal strength and erosion, uplift, and denudation rates of the Himalayas and Tibetan Plateau.

\section{Background}

\section{Evidence for shallow seismogenic slip}

A generally accepted model of subduction zone slip behavior (e.g., Moore and Saffer, 2001) places the thermally and material property-controlled seismogenic zone landward, with the outermost forearc décollement expected to be aseismic in velocitystrengthening unconsolidated materials (Wang and $\mathrm{Hu}, 2006$ ) (e.g., the Nankai and South Chile margins). Wells et al. (2003) and Song and Simons (2003) propose that megathrust slip is focused beneath the gravity low of a (forearc) basin. However, recent $\mathrm{Mw} 9+$ subduction megathrust earthquakes have challenged these models. The 2011 Tohoku-Oki earthquake showed that rapid and large slip could occur close to or at the trench, and the majority of the (southern) 2004 Sumatra-Andaman earthquake moment release occurred beneath the prism (e.g., Chlieh et al., 2007; Fujii and Satake, 2007) (Fig- 
ure F1). Further evidence supporting shallow slip offshore North Sumatra includes aftershock sequences within the outer prism (e.g., Peiscek et al., 2010; Engdahl et al., 2007; Tilmann et al., 2010) and small-scale fault scarps offsetting the seafloor generated by active thrust faults close to the deformation front that may be generated coseismically (Henstock et al., 2006). Slip during the 2005 Sumatra rupture was different: it was concentrated beneath the forearc islands and not beneath the seaward-tapered prism or the forearc basin (e.g., Briggs et al., 2006). Other margins have experienced ruptures beneath the forearc high similar to the 2005 rupture (e.g., Kamchatka 1952 and Chile 2010). Drilling the north Sumatran margin and focusing initially on its input materials will provide an accretionary margin site complementary to drilling at accretionary margins with thinner input sections (e.g., Nankai) and to the erosional Japan Trench margin, where extremely weak materials appear to have enabled very shallow and large slip (e.g., Chester et al., 2013).

The correspondence between the southern 2004 rupture location and the overlying prism plateau suggests a fundamental relationship between material properties, seismogenesis, and long-term evolution of the forearc. Coulomb wedge theory (Davis et al., 1983; Dahlen, 1984) predicts that variations in forearc surface slope reflect changes in basal fault dip or in the balance between the internal wedge strength and shear stress on the plate boundary. Wang and $\mathrm{Hu}$ (2006) predict an outer Coulomb wedge and an inner stable region that stores and releases elastic strain; accretion of "strong" input materials might limit the scale of the outer wedge, bringing stable behavior and coseismic slip seaward.

\section{Inputs to subduction zones and the role of a thick sedimentary input section}

The significance of input sediments for development of prism structure and morphology and décollement slip behavior in accretionary margins is well known. A number of ocean drilling projects have targeted input sites to address such questions (reviewed by Underwood, 2007). Key parameters for fault development and seismogenesis include clay and silica mineralogy (affecting diagenetic fluid release and frictional properties), hydrogeology (permeability, flow pathways, and pore fluid pressure), and thermal structure. The significance of thick input stratigraphy, where basal sediments are subjected to high temperatures and may be partially lithified, has recently been highlighted, for example at the north Sumatran margin where the input section is $4-5 \mathrm{~km}$ thick and includes high-velocity sediments at depth (Dean et al., 2010; Gulick et al., 2011; Geersen et al., 2013) and at the Makran margin where thicknesses reach $>7 \mathrm{~km}$ (Smith et al., 2012, 2013). At locations where thick sediment sections have accumulated over long time periods and are in thermal equilibrium for long periods of time, thus enhancing reaction progress for kinetically-driven diagenetic reactions, we might expect a higher degree of diagenesis and lithification that creates a seaward, shallowing shift in the transition from aseismic to seismogenic behavior, potentially to the trench. This strengthening effect could, however, be counteracted by buildup of high pore fluid pressures (e.g., Davis et al., 1983; Bangs et al., 2004; Saffer and Bekins, 2006). Within a submarine fan succession, including the relatively distal Nicobar Fan of the north Sumatran input section, there may be coarse-grained material that has contrasting shear strength, cementation, permeability (and hence fluid flow), and consolidation trends relative to finer grained materials (e.g., Spinelli et al., 2007). Coarser grained sediments may facilitate dewatering, minimize buildup of pore fluid pressure, and increase induration. Some sections of the north Sumatran input section are highly faulted (Figures
F6, F7, F8, F9); these faults may act as vertical permeability pathways that facilitate dewatering of this thick input system. Ultimately, the strength of deeply buried input sediments is a balance between (1) overpressure, such as may be generated by consolidation and dehydration reactions, which weakens materials, and (2) induration and cementation, which strengthen materials. In this input section, this balance is likely primarily controlled by permeability and heating.

\section{North Sumatran margin forearc structure}

Forearc structure and topography are strongly linked to plate interface seismogenic behavior (e.g., Wang and Hu, 2006), and both in turn reflect input material properties and their evolution. Several structural models have been proposed for what may control or contribute to the distinctive forearc plateau of the north Sumatran prism (including a passive roof duplex or bivergent wedge model; Fisher et al., 2007). These models for forearc growth are influenced by changes in sediment supply to the margin in terms of volume and properties; for example, passive roof duplexes along collisional mountain fronts are associated with thick, lithified foreland basin successions (Vann et al., 1986). The outer north Sumatran prism (and Nicobar prism to the north) is characterized by common landward-vergent or seaward-dipping thrusts (e.g., Karig et al., 1980; Moore et al., 1980; Henstock et al., 2006; McNeill and Henstock, 2014; Frederik et al., 2015). On other parts of the margin, seaward or mixed vergence is more common (e.g., Cook et al., 2014). This style of faulting is relatively unusual, although common to parts of the Cascadia subduction margin, and has been linked to low basal shear stress (e.g., Seely, 1977), a ductile basal layer (Gutscher et al., 2001), or development of a seaward-dipping backstop (Byrne and Hibbard, 1987). The unusual forearc geometry and fault style are both a function of material properties of the prism. Drilling results will help define the properties of incoming material that make up the forearc and its base, thus allowing models of forearc formation and prism fault geometry to be tested.

\section{Bengal-Nicobar Fan depositional history}

Regional initiation of the Bengal Fan is thought to be late Paleocene-middle Eocene (Curray and Moore, 1974). The Ninetyeast Ridge (NER) separates the Bengal Fan to the west from the Nicobar Fan to the east. The sediment accumulation rates of the fan system are most likely linked to tectonic uplift and erosion, monsoon intensity and resulting changes in continental run-off, potential glacial activity of the high altitude regions, and any catastrophic failure of the continental slope that released large sediment volumes in the sediment source areas. Analysis of drilling results prior to Expedition 362 and regional seismic profiles suggested there was a late Miocene regional unconformity linked to changes in collisional and/or intraplate deformation (e.g., France-Lanord et al., 2000). An apparently regional Pleistocene unconformity is also identified in seismic data (Curray and Moore, 1982) and in boreholes (e.g., Ocean Drilling Program [ODP] Leg 116 sites in Figure F3; Cochran, 1990). Accumulation rates on the Bengal Fan were relatively low from 7-8 Ma until 1 Ma (e.g., Leg 116 drill sites; France-Lanord et al., 1993). Overall sediment supply rates may have been increasing due to apparent intensification of the Indian monsoon from the late Miocene (e.g., Kroon et al., 1991). Southward progradation of the submarine fan is suggested to lead to a gradually decreasing age of the onset of fan deposition with distance south (e.g., von der Borch, Sclater, et al., 1974), but the NER is proposed to have blocked late Pleistocene-Recent transport of sediments to the Nicobar Fan and Sunda Trench (Curray and Moore, 1974; Moore et al., 1982). 
The nature and impact of intraplate deformation and climatic changes in the region at 7-8 Ma remain enigmatic. Sampling the Nicobar Fan can contribute to our understanding of monsoon initiation and intensification and Himalayan-Tibetan Plateau uplift history: if the late Miocene-Pliocene history is condensed in the Bengal Fan, then the Nicobar Fan section may prove crucial in deriving a more complete terrestrial erosional and submarine depositional history. A more complete history of sediment input buildup (linked to fan deposition) can also be correlated with information on when the current accretionary prism began to form, such as from exhumed material on the forearc islands (e.g., Karig et al., 1980).

Recent drilling of the Bengal Fan (e.g., IODP Expeditions 353 and 354) (Clemens, Kuhnt, LeVay, and the Expedition 353 Scientists, 2016; France-Lanord, Spiess, Klaus, Schwenk, and the Expedition 354 Scientists, 2016) provides new data on fan system history (Figure F3); these results will be incorporated into those from Expedition 362 to help direct postcruise research and to integrate results from the wider Indian Ocean region.

\section{Site survey data and seismic stratigraphy}

Most of the modern seismic reflection data within the region were collected between 2006 and 2009 and focus on the trench and forearc regions (e.g., Singh et al., 2008, 2010; Dean et al., 2010; Franke et al., 2008; Fisher et al., 2007; Gulick et al., 2011; Frederik et al., 2015). Details of the site survey seismic reflection data and data sources used for placing the Expedition 362 sites are provided in McNeill et al. (2016). Offshore North Sumatra, seismic profiles crossing the deformation front and trench (Figures F6, F7) show that the trench wedge overlies an angular unconformity (seismic Horizon A) that can be traced across the incoming plate (Dean et al., 2010; Geersen et al., 2015) to the Expedition 362 drill sites. Below seismic Horizon A, the well-layered, strongly reflective succession including channel complexes is interpreted as Nicobar Fan sediments with a change to less reflective sediments at depth (at seismic Horizon B or B*), which extend to acoustic basement (seismic Horizon D) and were interpreted prior to the expedition as pelagic sediments. The high-amplitude reflector described by Dean et al. (2010) and above, which may act as a décollement surface within the subduction zone, can also be traced from the trench and outer prism to the drill sites within the deep sediment section, where its polarity becomes positive and its amplitude reduces (seismic Horizon C). These horizons are shown in Figures F6, F7, F8, and F9 and described in more detail in Site U1480 summary and Site U1481 summary.

\section{Principal results}

\section{Site U1480 summary}

\section{Background and objectives}

Site U1480 (proposed Site SUMA-11C) is located on the Indian oceanic plate, east of the NER and west of the north Sumatran subduction margin (Figures F3, F4). The primary drilling objective at Site U1480 was to recover a complete section of the oceanic plate sedimentary section and the uppermost basaltic basement. Moving toward the trench, this stratigraphic section is overlain by the relatively rapidly deposited trench wedge, and eventually this section is subducted/accreted at the margin offshore North Sumatra. At the subduction deformation front, the sedimentary section is $4-5 \mathrm{~km}$ thick. Based on precruise seismic interpretation (Figures F6, F8), the sedimentary section at Site U1480 includes, from top to bottom,
- A thin, distal-sediment section of the trench wedge, which overlies an angular unconformity (seismic Horizon A);

- The Nicobar Fan succession, which includes a reflective section and an underlying nonreflective section separated by seismic Horizon B (the section below Horizon B was interpreted precruise as pelagic); and

- The pelagic prefan succession extending from seismic Horizon C to oceanic basement (seismic Horizon D).

The prominent seismic Horizon $\mathrm{C}$ is one of the potential candidates for the localization of the décollement (Dean et al., 2010). This site was targeted for drilling because it provides constraints on the initial physical, chemical, thermal, and mechanical properties and potentially the state of stress of the lower part of the input section where the plate boundary décollement develops, and it allows us to understand the material properties that may contribute to the formation of the unusual wide forearc plateau. Because the section thickens significantly on approaching the subduction zone (Figure F6), postcruise experiments and numerical modeling will evaluate the impact of increasing burial, temperature, and diagenetic alteration. Site U1480 will therefore allow us to address the three primary objectives (see Scientific objectives) to determine how the properties of the input section may lead to shallow seismogenic slip and unusual forearc/prism development. Site U1480 also offers the opportunity to obtain a complete section of the Nicobar Fan succession at $3^{\circ} \mathrm{N}$ where the onset of fan deposition was expected to be at 30-40 Ma (based on previous drilling and gradual fan progradation). The Nicobar Fan is separated from the Bengal Fan by the NER, and understanding its onset and growth is important for a complete sedimentary history of fan deposition related to Himalayan uplift, erosion, and monsoon development.

Site-specific objectives include

- Identifying the principal lithologies that may be involved in development of the broad prism and the plate boundary fault;

- Establishing how the mechanical/strength properties of the different lithologies change with depth to determine the effects of burial rate and burial time and identify potential discontinuities that may be candidates for detachment positions;

- Identifying any thermal history indicators and effects of early diagenesis and establishing the present-day thermal structure of the section;

- Identifying fluid sources and changes with depth; and

- Determining the principal sources of sediment delivered to the site (in particular sediments above seismic Horizon C) and changes in source with time. Potential sources include the Himalaya and Ganges-Brahmaputra floodplain through the Bengal Fan system, the Irrawaddy River fed by the Indo-Burman range, the Sunda forearc, the Sumatran mainland (including volcanic arc), and the NER.

Site U1480 is located at $3^{\circ} 2.04^{\prime} \mathrm{N}, 91^{\circ} 36.35^{\prime} \mathrm{E}$, in a water depth of $4148 \mathrm{~m}$ (Figures F3, F5; Table T1). The operational goals at this site were to core the entire sedimentary section and reach the sediment/basement interface and to log the section. Hole U1480E was cored to 99.7 meters below seafloor (mbsf) but was terminated short of its target depth (see Operations in the Site U1480 chapter [McNeill et al., 2017b]). Hole U1480F penetrated to 815 mbsf. Hole U1480G had a reentry system installed and was cased to $754 \mathrm{mbsf}$, followed by coring to $1431.6 \mathrm{mbsf}, \sim 17 \mathrm{~m}$ into igneous basement. Hole $\mathrm{U} 1480 \mathrm{H}$ penetrated to $129.4 \mathrm{mbsf}$ and is an additional shallow hole for biostratigraphy, paleomagnetism, geochemistry, and micro- 
Table T1. Expedition 362 operations summary. ${ }^{*}=$ missed mudline, $\dagger=$ reentry system. $N A=$ not applicable, $-=$ no data. Download table in.$c s v$ format.

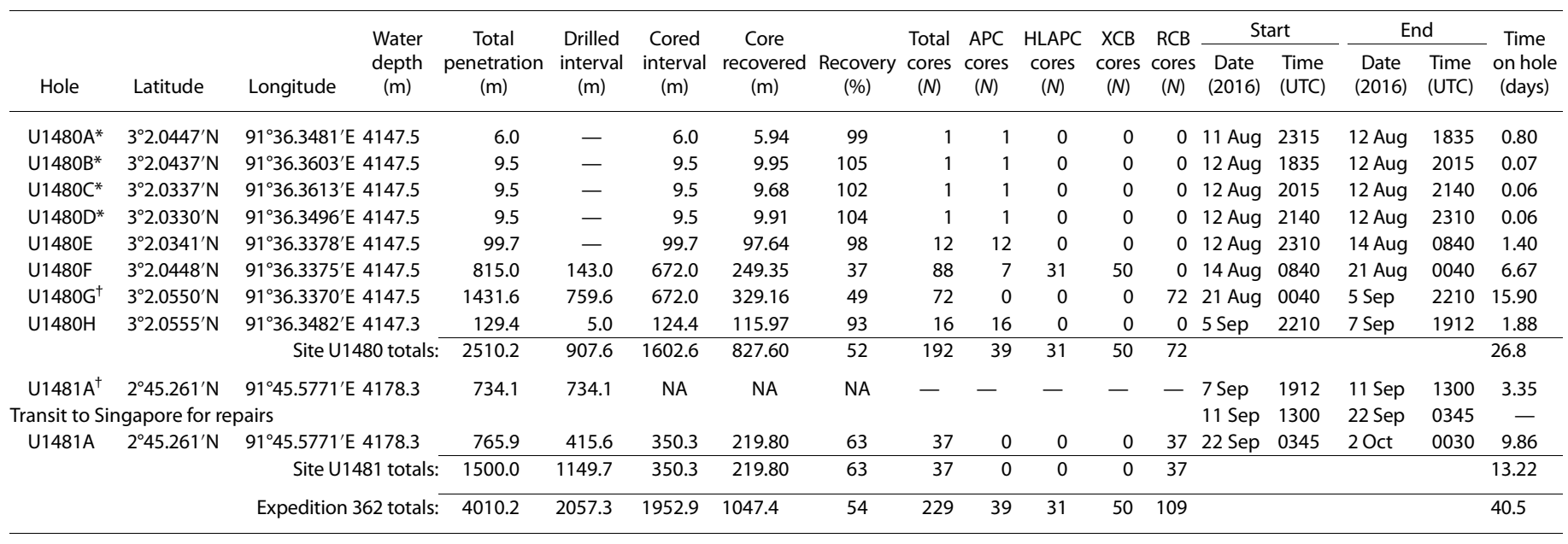

biology. Limited logging was conducted in Hole U1480G (a limited tool string within the casing and to $\sim 50 \mathrm{~m}$ below casing), and formation temperature measurements were taken in Holes U1480E, U1480F, and U1480H. Holes U1480A-U1480D missed the mudline and were not studied extensively.

\section{Sedimentology and petrology}

Sediment and sedimentary rock were recovered from the seafloor to $1415.35 \mathrm{mbsf}$ in eight holes (U1480A-U1480H). At the base of this interval, beneath the sedimentary cover, igneous extrusive and intrusive rocks are interbedded with volcaniclastic sediments. This is underlain by a thin interval (1415.35-1431.63 mbsf) of basaltic crustal rock of the igneous basement. The sediments represent a Late Cretaceous to Recent deep-marine sedimentary cover that accumulated between the NER and the Sunda subduction zone.

Lithostratigraphic definitions for Site U1480 were based exclusively on cores recovered from Holes U1480E-U1480G. The sediments were mostly unlithified to partially lithified, with lithified materials being encountered in intervals near basement. The main lithologies are nannofossil-bearing mud, siliciclastic mud, and siliciclastic sand. Dominant siliciclastic lithologic variants are clay (claymineral dominated), silty clay, and fine-grained sand. Six lithologic units were identified (Units I-VI) based on major lithologic changes (Figure F10). Subunits were defined where minor but distinct lithologic changes occurred within units. The overall succession consists of predominantly siliciclastic sediments deposited from various sediment gravity-flows (e.g., turbidity currents and debris flows), interpreted as Nicobar Fan, underlain by mixed tuffaceous and pelagic sediments and a series of intercalated pelagic and igneous materials overlying ocean crust.

Unit I consists of Subunits IA-IC. Subunit IA (0-5.60 mbsf) is dominated by calcareous clay with minor biosiliceous and ash components. Subunit IB (5.60-18.80 mbsf) is characterized by finegrained sand and clay, with minor calcareous clay and ooze. Subunit IC (18.80-26.42 mbsf) contains silty clay and calcareous clay with minor ash.

Unit II consists of Subunits IIA-IIC. Subunit IIA (26.42-343.67 mbsf) comprises layers of thin- to medium-bedded, laminated to structureless sandy silt and fine-grained sand, with silty clay and silt. Subunit IIB (343.67-785.80 mbsf) contains alternating thin- to very thin bedded, cross- and parallel-laminated silt and clay. Subunit IIC
(785.80-1250.35 mbsf) is bioturbated black and dark gray clay/claystone and silty clay/claystone and structureless muddy sand/sandstone with plant material and mud clasts.

Unit III consists of Subunits IIIA and IIIB. Subunit IIIA (1250.35-1310.02 mbsf) is dominated by gray-green and minor reddish brown claystone with agglutinated foraminifers. Subunit IIIB (1310.02-1327.23 mbsf) is dominated by reddish brown tuffaceous silty claystone with biosiliceous debris and minor chalk. Unit III has a marked increase in lithification relative to overlying Unit II and an absence of micaceous quartzofeldspathic silt and sand.

Unit IV (1327.23-1349.80 mbsf) is composed of basaltic flows, tuffaceous and volcaniclastic sandstone, and volcanic breccia.

Unit V (1349.80-1415.35 mbsf) is defined mainly on the basis of the appearance of calcareous claystone and chalk and intercalated magmatic intrusions.

Unit VI (1415.35-1431.6 mbsf) is basalt that is interpreted as ocean crust. It consists of fine- to medium-grained plagioclase- and pyroxene-bearing seriate-textured basalt with low vesicle content $(<1 \%)$. An overall moderate to high alteration state is indicated by a brownish color and the occurrence of mineral-filled fractures.

\section{Structural geology}

Deformation structures at Site U1480 are rare, and subhorizontal bedding dips are preserved. In a few instances, bedding dips are $>10^{\circ}$ and related to slumping. Sand and mud injections into overlying strata were also observed. Rare vein structures are identified in limited intervals. Additionally, a limited $20 \mathrm{~m}$ interval in Subunit IIIB exhibits a variety of fault and shear zone structures, many of which appear in conjugate geometries. These centimeter-scale shear zones are oriented at a high angle to bedding. In this interval, cross-cutting fault relationships, fault-bedding cut-off angles, and cross-cutting and overprinting relationships of diagenetic fabrics (flattened oxidation spots) suggest that this deformation occurred before or during the earliest parts of deposition of the overlying Nicobar Fan succession. Although rare faults are observed in clusters in the overlying Nicobar Fan interval, many can be associated with synsedimentary structures such as recumbent isoclinal folds interpreted as indicators of sediment slumping processes. We found no compelling evidence for deformation associated with the steep faults that cut the seafloor imaged on seismic reflection data near the site (Figure F8). 
Figure F10. Summary diagram of data from Site U1480. Seismic panel presented in depth based on time-depth tie at the seafloor and 1431 mbsf. Graphic lithology and lithologic units are defined by sediment composition and texture. Natural gamma radiation, magnetic susceptibility (MSL $=$ magnetic susceptibility logger, MSP = point magnetic susceptibility), $P$-wave velocity (discrete samples), and MAD porosity were measured as part of the standard physical properties core flow. Chloride and silica are examples of the routine pore fluid geochemical measurements (see also Hüpers et al., 2017). Stratigraphic ages from biostratigraphic and magnetostratigraphic analysis of core samples (see also McNeill et al., 2017b). Small ticks in the Age column differentiate subepoch boundaries.

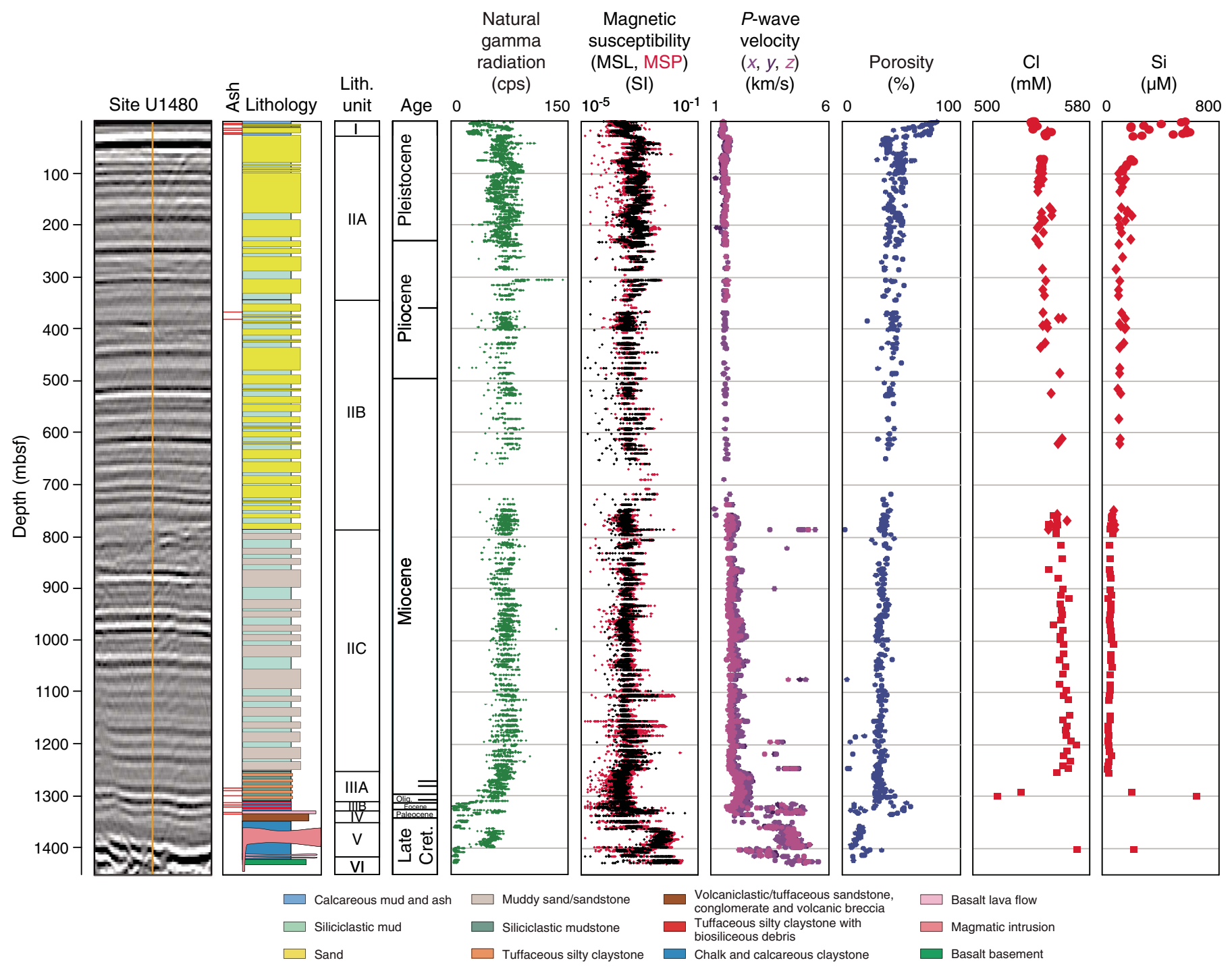

Detailed description and analysis of the type and intensity of drilling deformation structures and drilling conditions were used to make qualitative assessments of formation strength and lithology. For example, a more stable and intact wellbore is suggested by lack of fall-in material at the base of Unit II and is supported by the relative absence of drilling deformation structures. The most important finding from the preliminary evaluation of drilling conditions is the recognition of sand-rich sections in intervals of poor $(<10 \%)$ recovery. Fast drilling appears to be correlated with high-sand fractions, so intervals of low recovery with fast drilling are interpreted as sand rich. Preliminary analysis of drilling conditions in Hole U1480G and correlation with physical property data may help define additional potential fault localization horizons.

\section{Biostratigraphy}

The biostratigraphy of the $\sim 1400$ m thick sedimentary succession cored at Site U1480 was based on calcareous nannofossils, planktonic foraminifers, diatoms, radiolarians, and silicoflagellates. Calcareous microfossils occur discontinuously and mostly in low abundances throughout the succession. Biosiliceous microfossils occur in two short intervals (0-26 and 1255-1315 mbsf). Biostratigraphic data suggest an average sedimentation rate of $>100 \mathrm{~m} / \mathrm{My}$ from the seafloor to 1270 mbsf within the Nicobar Fan succession, from the late Miocene to Recent. A Pleistocene condensed section and/or hiatus of $\sim 0.6 \mathrm{My}$ is identified. Below $1270 \mathrm{mbsf}$, average sedimentation rates decrease to $<4 \mathrm{~m} / \mathrm{My}$. McNeill et al. (2017a) provide a detailed analyses of the sedimentation history at Site U1480. The low average sedimentation rates below 1270 mbsf may suggest the presence of several hiatuses in the Paleocene through early Miocene interval. Paleocene sedimentation rates are also distorted by the occurrence of $60 \mathrm{~m}$ of igneous intrusions and volcanic breccias. The oldest sediments sampled in Hole U1480G are of late Maastrichtian (Late Cretaceous) age. The Late Cretaceous/Paleo- 
cene boundary (66.0 Ma) was not recovered due to the presence of a hiatus.

\section{Paleomagnetism}

At Site U1480, we made stepwise alternating field (AF) demagnetization measurements on all archive-half core sections. To confirm the magnetic properties observed from the section halves, discrete samples taken from working-half sections were subjected to AF and thermal demagnetization. Variations in the natural remanent magnetization (NRM) intensity generally correlate with lithology. Paleomagnetic measurements indicate that the calcareous clay and calcareous ooze in Unit I (0-26.42 mbsf) have a mean NRM intensity of $3 \times 10^{-2} \mathrm{~A} / \mathrm{m}$, whereas the fine sand with clay in Subunit IC (18.8-26.42 mbsf) has lower NRM intensity $\left(\sim 1 \times 10^{-3} \mathrm{~A} / \mathrm{m}\right)$. The NRM intensity remains constant $\left(\sim 3 \times 10^{-2} \mathrm{~A} / \mathrm{m}\right)$ for the silt and bioturbated clay in Unit II (26.42-1250.35 mbsf) and the grayish green and reddish brown clay in Unit III (1250.35-1310.02 mbsf). NRM intensity ranges between $5 \times 10^{-3}$ and $\sim 5 \times 10^{-2} \mathrm{~A} / \mathrm{m}$ for the mafic rocks and volcaniclastic sand and mud in Units IV and $\mathrm{V}$ and increases to several amperes per meter for the basaltic basement in Unit VI. Many discrete peaks of higher NRM and magnetic susceptibility values in both Units II and III can be tied directly to the presence of ferrimagnetic greigite.

NRM inclinations are strongly biased toward the vertical (mostly toward $+90^{\circ}$ ) in the majority of the cores due to remagnetization imparted by the coring process. For sediment cores, AF demagnetization to $10 \mathrm{mT}$ is effective in removing the drilling overprint for a high percentage of samples, as shown by a decrease in magnetization intensity and by a shift of inclinations toward shallower values that are comparable to the inclination expected for the site (approximately $\pm 6^{\circ}$ ). NRM declinations of APC cores before orientation correction differ significantly, as expected. Orientation correction using the data from the Icefield MI-5 and FlexIT orientation tools indicates the remanence is of primary origin. Declinations and inclinations in Hole U1480E and U1480H cores are very similar for the upper $\sim 40 \mathrm{~m}$, which strongly attests to the fidelity of the paleomagnetic record and indicates a common chronology for both holes.

Constructing a magnetostratigraphy for Site U1480 requires a correlation between the measured polarity pattern and the geomagnetic polarity timescale (GPTS) as well as using biostratigraphic constraints. At a low-latitude area such as Site U1480, a near $180^{\circ}$ shift in declination in the cores, is a more reliable sign of a polarity transition than a change in inclination sign. Based on declination data, the Brunhes/Matuyama Chron boundary $(0.78 \mathrm{Ma})$ is placed at $18.5 \mathrm{mbsf}$, and the sediments between 28 and $31 \mathrm{mbsf}$ may represent the Jaramillo Subchron (0.988-1.072 Ma). The position of other chron boundaries deeper in the hole requires further investigation. We note that these results are not perfectly matched with those from biostratigraphy, and this will be investigated further in postcruise research.

\section{Geochemistry}

A total of 175 whole-round (WR) samples were collected from holes drilled at Site U1480. In addition, high-resolution water samples were obtained with Rhizon samplers between 74 and 99 mbsf in Hole U1480H. Geochemical profiles of the dissolved constituents in the pore fluids reflect the combined effects of organic matter diagenesis, alteration of volcanogenic sediments, and reactions in oceanic basement.
In the upper $200 \mathrm{~m}$, pore fluid geochemical data reveal organic matter remineralization, with the depth of the sulfate-methane transition zone (SMTZ) at $~ 120$ mbsf. Within this zone, there is an increase in alkalinity, phosphate, and ammonium over seawater values, as expected from organic matter diagenesis. However, we observe maxima in phosphate at 20 and $100-120$ mbsf, which may reflect regional lateral fluid transport. In the upper $200 \mathrm{~m}$, there is ample evidence for alteration of volcanic ash and associated smectite formation, as indicated by changes in dissolved silica and potassium. The K and Si profiles (Figure F10) suggest zeolite formation between 300 and $450 \mathrm{mbsf}$, which is consistent with the presence of zeolite in the recovered sediment. Samples collected between 1250 and 1300 mbsf show pronounced concentration changes in most of the dissolved cations: a decrease in chloride, sodium, and magnesium and attendant increases in calcium, boron, lithium, and silica. A single sample collected at 1403 mbsf shows a distinct reversal in the silica, magnesium, and chloride gradients. Collectively, these concentration changes point to dehydration reactions between 1250 and at least 1300 mbsf. Hüpers et al. (2017) provide detailed analysis on the source and timing of the deep chloride anomaly and implications for seismogenesis. Deeper in the sediment section, an increase in chloride (Figure F10), strontium, and calcium and a decrease in magnesium indicate a contribution from basement fluid. Superimposed on these trends, dissolved calcium and strontium notably decrease between $\sim 800$ and 1200 mbsf, which is consistent with carbonate cementation observed in the cores.

Headspace gas analyses show that methane concentrations are generally low, and changes in methane concentration and methane/ethane ratio align with lithologic unit boundaries. Detectable methane concentrations were observed from just below the SMTZ to the base of Subunit IIA. Methane was not detected in Subunit IIB, which may reflect the slightly lower organic carbon contents here. Methane levels increase again and ethane becomes detectable in Subunit IIC, which may represent the onset of thermogenic methane production. Samples from Unit III show a slight decrease in methane as well as a decrease in the methane/ethane ratio. Methane concentrations drop significantly in Units IV and V, where volcaniclastic sediments and igneous rocks are prevalent.

Total organic carbon (TOC) and carbonate contents are elevated in Unit I, reaching maxima of $1.8 \mathrm{wt} \%$ TOC and $40 \%$ carbonate in the nannofossil ooze layers of Unit I. Carbonate content is low throughout Subunits IIA and IIB, with minor peaks at 475.1 and $698.3 \mathrm{mbsf}$, and near the Subunit IIB/IIC boundary at $786 \mathrm{mbsf}$. Carbonate content reaches a maximum of $94 \%$ at 1315 mbsf, within the chalk of Unit III. Organic carbon to total nitrogen ratios show a distinct signature of terrigenous input in the sediments of Unit I and Subunit IIA but remain within the range characteristic of marine organic matter deeper than 200 mbsf.

\section{Physical properties}

Natural gamma radiation (NGR), magnetic susceptibility (MS), gamma ray attenuation (GRA) bulk density, and $P$-wave velocity were measured using the Whole Round Multisensor Logger (WRMSL). Discrete $P$-wave velocity and moisture and density (MAD) were measured on working-half sections. Undrained shear strength was measured in the uppermost $370 \mathrm{~m}$ using the automated shear vane and pocket penetrometer. Thermal conductivities were measured on WR core sections (soft sediment) and pieces from working-half sections (hard rock). For most lithologic unit boundaries, we see general shifts in physical properties; however, 
there are some NGR and velocity excursions that occur within lithologic units (Figure F10).

NGR values are generally low in lithologic Unit I, with significant variability between 24 and 89 counts/s. Within lithologic Units II and III, NGR values are relatively constant. NGR values then sharply decrease near the base of lithologic Unit III. NGR is generally low in Units IV-VI where igneous sediments and rocks are present, although higher NGR values occur where clay-rich pelagic sediment is present in lithologic Unit V.

Magnetic susceptibility shows a distinct shift to higher values at the Unit I/II boundary and to lower values at $~ 1250 \mathrm{mbsf}$ at the Unit II/III boundary. Within Unit II, magnetic susceptibility values decrease slightly with increasing depth. Magnetic susceptibility has relatively low values in the sand and clay in the upper and middle portions of Hole U1480G, reaches its lowest values in calcareous sediments, and increases to its highest values in the volcaniclastic sediments and igneous rocks at the base of the hole.

Porosity values determined from MAD analyses generally decrease with depth. Near-seafloor porosity is $\sim 80 \%$, and values decrease rapidly to mean values of $\sim 46 \%$ at $100 \mathrm{mbsf}$ and then decrease more slowly to $\sim 31 \%$ at 1320 mbsf. The porosity values calculated deeper than $\sim 1300$ mbsf deviate from an overall consolidation trend, with subsets of both higher and lower porosities. MAD bulk density values generally increase with depth. Bulk density is $<1.5 \mathrm{~g} / \mathrm{cm}^{3}$ at the seafloor and increases rapidly until $30 \mathrm{mbsf}$, followed by a slower increase to $\sim 2.2 \mathrm{~g} / \mathrm{cm}^{3}$ at $1320 \mathrm{mbsf}$. The most striking changes in physical properties occur between 1305 and 1361 mbsf where porosity and bulk density show both high and low values, grain density is low, and $P$-wave velocity is high. The cause of these changes may result from lithologic heterogeneity (tuffaceous, biosiliceous, and calcareous rocks), diagenetic reactions that may have expelled fluid, or migration of fluid into this interval (see also Hüpers et al., 2017).

To complement WRMSL $P$-wave velocity measurements, more than 3000 caliper velocity measurements were made on cores and core samples, providing a comprehensive compressional wave data set (Figure F10). $P$-wave velocity values gradually increase with depth and show a distinct increase deeper than 1300 mbsf. A few intervals show distinct increases in $P$-wave velocity, including a $\sim 500 \mathrm{~m} / \mathrm{s}$ increase at $\sim 1250 \mathrm{mbsf}$ and marked increases within the igneous rocks where velocities exceed $5000 \mathrm{~m} / \mathrm{s}$. Generally, the $x$ and $y$-direction $P$-wave velocities are higher than the $z$-direction values, with velocity anisotropy values averaging $\sim 10 \%$.

In general, thermal conductivity values increase slightly with depth, from $\sim 1.0$ to $\sim 2.3 \mathrm{~W} /(\mathrm{m} \cdot \mathrm{K})$. Thermal conductivity values range from 0.2 to $1.6 \mathrm{~W} /(\mathrm{m} \cdot \mathrm{K})$ in the sand and clay, from 1.0 to 5.5 $\mathrm{W} /(\mathrm{m} \cdot \mathrm{K})$ in the pelagic sediments, and from 0.5 to $3.0 \mathrm{~W} /(\mathrm{m} \cdot \mathrm{K})$ in the volcaniclastic sediments near the base of the hole.

\section{Downhole measurements}

The downhole measurements originally scheduled at Site U1480 included formation temperature measurements with the APCT-3 and T2P, formation pressure measurements with the T2P, and a complete suite of logging tools. Because of tool failure during the deployment of the T2P and unstable conditions in the two holes planned for logging, the downhole measurements made at Site U1480 consisted of 11 successful formation temperature measurements with the APCT-3 to a depth of $\sim 210 \mathrm{mbsf}$ and a reduced set of logs through the casing and in $52 \mathrm{~m}$ of open hole below casing in
Hole U1480G. The 11 formation temperature measurements define a linear temperature profile with a gradient of $44.4^{\circ} \mathrm{C} / \mathrm{km}$. Combined with an average of thermal conductivity values measured on cores, the vertical conductive heat flow is $75 \mathrm{~mW} / \mathrm{m}^{2}$, which is in agreement with the broad range of values in the area.

Because of unstable borehole conditions in Hole U1480G, we deployed a short $(19 \mathrm{~m})$ tool string made of a spectral gamma ray tool and a resistivity tool. The tools were unable to go deeper than $\sim 809$ mbsf ( $\sim 2 \mathrm{~m}$ below the casing). Within the casing, the gamma ray data display little variability due to the dampening effect of the casing. In the open hole below casing, the gamma ray data show a general increase from $\sim 50$ to $\sim 90$ gAPI. The separation of the different depth of investigation resistivity logs suggests that the hole was enlarged, which is consistent with the unstable hole in this interval.

\section{Core-log-seismic integration}

The two main integration activities carried out at Site U1480 were correlation of depths between the different holes and linking core observations to the site survey seismic data. Because logging was limited due to the instability of the hole, alternate strategies were used.

A good correlation of the cores between Holes U1480A$\mathrm{U} 1480 \mathrm{E}$ and $\mathrm{U} 1480 \mathrm{H}$ was established, and a composite depth scale was developed. The correlation is primarily based on NGR and magnetic susceptibility measurements but is also consistent with WRMSL $P$-wave velocity and GRA density and color reflectance values $\left(\mathrm{L}^{*}, \mathrm{a}^{*}, \mathrm{~b} *\right)$ measured on split cores. Because Holes U1480AU1480D did not recover the mudline, this correlation was necessary to determine the relative and absolute positions of the cores. Comparison between Holes U1480E and U1480H from the seafloor downhole to 30 mbsf shows that although each has $>100 \%$ recovery, there are gaps in the material sampled between cores. This composite depth scale will permit future sampling at higher resolution. Deeper than 30 mbsf, physical property records from the holes are consistent, but construction of an actual detailed composite section is not possible.

Correlation between the cores (recovered in depth) and the site survey seismic data (recorded in time) requires a time-depth relationship. It became apparent during drilling that the $P$-wave velocities obtained from the cores would not be sufficient to independently develop this relationship, and planned sonic logs and a vertical seismic profile were not obtained because of unstable hole conditions. However, variations from core observations and measured $P$-wave velocities did provide estimates of the positions of distinctive features for correlation with the seismic data. These were used to create a series of tie points, including two initial reference depths provided by the seafloor and acoustic basement and an additional control point that used a continuous record of drilling parameters to establish the depth of a large-scale channel prominent on the seismic profile. Overall, this correlation between core properties and seismic data provided a solid framework to tie core and seismic data (Figure F10).

\section{Background and objectives \\ Site U1481 summary}

Site U1481 (proposed Site SUMA-12A) is located on the Indian oceanic plate, east of the NER and west of the north Sumatran subduction margin and $35 \mathrm{~km}$ southeast of Site U1480 (Figures F3, F4, F5). The primary drilling objectives at Site U1481 were 
- To core the deeper interval of the subduction input sedimentary section and basement;

- To determine if the lower Nicobar Fan, pelagic section, and basement at Site U1480 are representative of this part of the Indian plate; and

- To understand the degree of heterogeneity of sediment and basement over short distances.

Drilling without coring (to $\sim 1150 \mathrm{mbsf}$ ) and installing a reentry/casing system minimized the duration of open-hole operations and thus offered an increased chance of successful wireline logging and deep coring. Based on seismic interpretations, the sedimentary section at Site U1481 is similar to that at Site U1480 and includes

- A thin, distal trench wedge section underlain by an unconformity (seismic Horizon A);

- The Nicobar Fan succession composed of an upper reflective section and a deeper, less reflective section separated by seismic Horizon B* at Site U1481;

- The prefan succession that underlies the Nicobar Fan sediment. Integration of seismic data with results from Site U1480 cores predicted these two units to be separated by seismic Horizon C; and

\section{- Acoustic basement (seismic Horizon D marks its top) (Figures} F7, F9).

Seismic Horizon $\mathrm{C}$ was previously identified as a potential horizon for localization of the décollement at the subduction zone. The deeper part of the stratigraphic section at Site U1481 was targeted for coring and logging because it includes (1) many of the potential horizons that may evolve into the plate boundary décollement in the shallow and deep subduction zone and (2) sedimentary and basement materials that may be sources of fluids influencing fault slip behavior. Cores and logs provide constraints on the initial lithologic, physical, chemical, and mechanical properties and potentially the state of stress of the lower part of the input section where the plate boundary fault develops. The sedimentary section thickens significantly on approaching the subduction zone, and postcruise experimental and numerical modeling work will be used at this site, as at Site U1480, to constrain the impact of increasing burial, temperature, fluid interactions, and diagenetic alteration. Site U1481 will therefore allow us to address the three primary expedition objectives to determine how the properties of the input section may lead to shallow seismogenic slip and to unusual forearc development as related to the basal properties of the prism (see Scientific objectives). Site U1481 also offers the opportunity to test local variations in pre- and early Nicobar Fan deposition through comparison with Site U1480.

Specific objectives included

- Establishing the onset of Nicobar Fan deposition and determining the principal sources of sediment delivered to the site during early fan history;

- Identifying the principal lithologies that may be involved in development of the plate boundary fault;

- Establishing how the mechanical/strength properties of the different lithologies change with depth to determine trends and effects of burial rate and burial time and identifying potential discontinuities that may be candidates for detachment positions;

- Identifying any thermal history indicators and any effects of early diagenesis;
- Identifying fluid sources and changes with depth;

- Determining the composition and origin of basement at the site and its effect on overlying sediments; and

- Comparing the lithostratigraphy, geochemistry, and physi$\mathrm{cal} /$ mechanical properties with those at Site U1480 to establish local variations of the stratigraphic succession.

Site U1481 is located at $2^{\circ} 45.29^{\prime} \mathrm{N}, 91^{\circ} 45.58^{\prime} \mathrm{E}$, in a water depth of $4178 \mathrm{~m}$ (Figures F3, F5; Table T1). Hole U1481A was cased to $730.5 \mathrm{mbsf}$, drilled to $1149.7 \mathrm{mbsf}$, and penetrated to $1500 \mathrm{mbsf}$ with RCB coring from 1149.7 to 1500 mbsf. Wireline logging was conducted within the casing and in the open hole with log data successfully obtained to $6 \mathrm{~m}$ from the bottom of the hole (data to 1494 mbsf).

\section{Sedimentology and petrology}

Site U1481 was drilled to investigate local variations of the lower part of the Nicobar Fan and underlying pelagic sediments and basement. Sediment and sedimentary rock were recovered from 1149.7 to $1500 \mathrm{mbsf}$ in Hole U1481A. Overall, the succession at Site U1481 consists of siliciclastic sediments interpreted as the lower part of the Nicobar Fan and intercalated pelagic sediments in the deepest section (Figure F11). Because of time constraints, coring into the deepest prefan pelagic sediments and basement was not possible. The sediments represent the early to late Miocene deep-marine sedimentary cover between the NER and the Sunda subduction zone. Site U1481 is located $\sim 35 \mathrm{~km}$ southeast of Site U1480 (Figure F5).

Two major lithologic units were identified (Units II and III; Figure F11) and are correlated to those observed at Site U1480. Unit II (1149.70-1360.12 mbsf) is composed of bioturbated black and dark gray clay/claystone and silty clay/claystone and structureless muddy sand/sandstone with plant material and mud clasts. Unit II sediments are mostly unlithified, but localized lithified materials were encountered (carbonate-cemented sandstone and mudstone). The base of Unit II marks a transition into sediments that are lithified. Unit II is equivalent to Subunit IIC at Site U1480 (Figures F10, F11). Unit III contains gray-green and minor reddish brown claystone (1360.12-1498.72 mbsf) with agglutinated foraminifers. Unit III is equivalent to Subunit IIIA at Site U1480 (Figures F10, F11). Two notable differences with Site U1480 are that the lower part of Unit III at Site U1481 ( 1400-1498.72 mbsf) contains more tuffaceous material than in Site U1480 Subunit IIIA, and there are intercalated sandstones present at Site U1481, which were absent in the deeper succession at Site U1480.

\section{Structural geology}

The recovered section at Site U1481 is generally undeformed without any evidence of deformation associated with the fault zones identified on seismic reflection data as close as $\sim 3 \mathrm{~km}$ from Site U1481 (Figure F9). Bedding dips are subhorizontal throughout the cored section, and the rare faults that were discovered, especially in Unit III around $1460 \mathrm{mbsf}$, cannot be confidently interpreted as natural tectonic structures. Some faults may be natural faults overprinted by drilling deformation. Synsedimentary deformation structures associated with slumping, such as microfaults and folds, are common in Unit II and present in Unit III.

Drilling disturbance is concentrated deeper than 1325 mbsf. Shallower than that depth, sections with undisturbed core are common; where the core is affected by drilling, biscuits form with only moderate intensity. Deeper than 1325 mbsf, severe deformation by 
Figure F11. Summary diagram of data from Site U1481. Seismic panel presented in depth based on time-depth tie at the seafloor and 1500 mbsf. Graphic lithology and lithologic units are defined by sediment composition and texture. Natural gamma radiation, magnetic susceptibility (MSL = magnetic susceptibility logger, MSP = point magnetic susceptibility), $P$-wave velocity (discrete samples), and MAD porosity were measured as part of the standard physical properties core flow. Chloride and silica are examples of the routine pore fluid geochemical measurements (see also Hüpers et al., 2017). Stratigraphic ages from biostratigraphic and magnetostratigraphic analysis of core samples (see also McNeill et al., 2017b). Small ticks in the Age column differentiate subepoch boundaries.

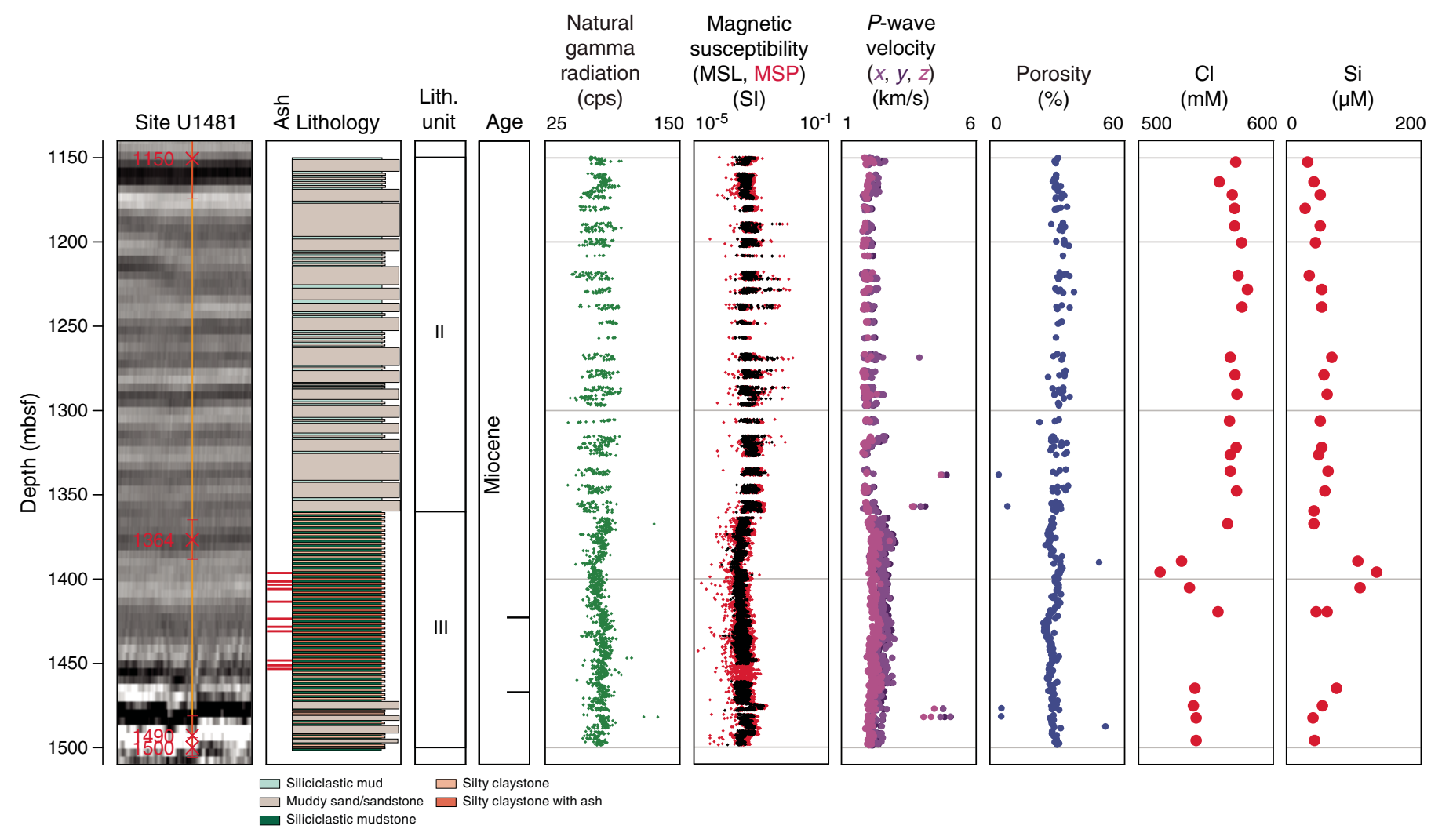

fractures, biscuits, and breccias is common. Within drilling biscuits that are as long as $50-80 \mathrm{~cm}$, many fractures developed that created core segments. Fractures developed over time after the core was split, and in intervals between the most fractured core, cores lengthened (up to $2 \%$ expansion). Fracturing and core expansion appear to reflect core unloading, and this process is limited to Unit III. Drilling conditions data appear to reflect first-order physical property trends and bear further evaluation in postcruise studies.

\section{Biostratigraphy}

Planktonic foraminifers were occasionally observed in low abundance in the upper $200 \mathrm{~m}$ of the $350 \mathrm{~m}$ cored interval; the rest of the section is barren. Diatoms and radiolarians occur in two intervals, 1370-1411 and 1496-1497 mbsf. Rare calcareous nannofossils occur discontinuously in a few samples in all three of the above intervals. The few available age-indicative species were used to establish sediment accumulation rates. The tie points used result in sediment accumulation rates that fit virtually all biostratigraphic data. The uppermost tie point is provided by a calcareous nannofossil assemblage, the middle tie point by a radiolarian assemblage, and the deepest tie point by a combination of radiolarian and diatom assemblages.

\section{Paleomagnetism}

Shipboard paleomagnetic studies for Site U1481 consisted of continuous measurements of archive-half core sections and pro- gressive demagnetization measurements of discrete samples from working-half sections. Within the recovered rocks, there are considerable variations in magnetic properties and demagnetization behavior among the various lithologies. The intensities of NRM of the archive halves span more than two orders of magnitude. Variations of magnetic properties between different lithologies are similar to those observed at Site U1480. Overall, sediments in Unit II (1149.70-1360.12 mbsf) have relatively high NRM intensity (averaging $\sim 21 \mathrm{~mA} / \mathrm{m}$ ) compared to those of the gray-green and minor reddish brown claystone in Unit III (1360.12-1498.72 mbsf) with an average NRM intensity value of $\sim 5 \mathrm{~mA} / \mathrm{m}$. In the lower part of Unit III ( 1400.00-1498.72 mbsf), NRM shows a stepwise increase, from $\sim 2.5 \mathrm{~mA} / \mathrm{m}$ (at $1400 \mathrm{mbsf}$ ) to $\sim 5.0 \mathrm{~mA} / \mathrm{m}$ (at the bottom of the hole; $1498.72 \mathrm{mbsf}$ ), potentially resulting from a change in depositional environment and perhaps associated with the reddish brown silty claystone and fine- to very fine grained sandstone in these depth intervals. Variations in magnetic susceptibility are consistent with the variations in NRM intensity. Inclinations from discrete samples are mostly concentrated at $\pm 15^{\circ}$, suggesting that these samples record an inclination close to the theoretically predicted value for the latitude of this site in the late Miocene and indicating they may represent the primary remanent magnetization.

\section{Geochemistry}

The geochemical composition of fluids in the deeper sediment section of Site U1481 provides a contrasting view to the data from 
Site U1480 and will help us evaluate how fluid-rock interactions between these two sites may relate to variations in stratigraphy, lithology, and physical properties. These variations in turn affect the state and geomechanical properties of the input sediments before and during subduction. We analyzed a total of 28 IW samples at a frequency of 1 or 2 samples per core from Cores 362-U1481A-2R through 38R (1149.70-1498.72 mbsf). Whereas there are similarities in the dehydration reactions that may lead to fluid production at depth (see Hüpers et al., 2017), the differences in sediment composition of lithologic Unit III at Site U1481 and Subunit IIIA at Site U1480 are reflected by a lack of a pronounced increase in B and Mn at Site U1481 at the horizon of observed fluid freshening, marked by low $\mathrm{Cl}$ (Figures F10, F11). Deeper in the section, basement was not reached at Site U1481, and thus we do not have a clear indication of the effect that diffusion of ions from (or into) the basement aquifer may have on the pore fluid geochemistry at depth at this site. Relative to Site U1480, calcium at Site U1481 is relatively constant, magnesium is depleted to a lesser degree, and there is no indication of sulfate contribution from the basement.

Organic geochemistry results are similar to those from Site U1480. Headspace samples taken to monitor hydrocarbon contents show methane levels between 144 and 4503 ppmv, well below the limits designated by the safety policy. Ethane and propane were also detected, although at much lower concentrations, and the methane/ethane ratio suggests hydrocarbon production remains primarily biogenic. Total carbon and carbonate concentrations are generally low at Site U1481, similar to the corresponding units of Site U1480. Organic carbon concentrations are also generally similar to those at Site U1480, but several elevated organic carbon values appear to reflect strong and localized input of terrigenous organic material based on the $\mathrm{C} / \mathrm{N}$ ratios.

\section{Physical properties}

NGR, magnetic susceptibility, GRA bulk density, and $P$-wave velocity were measured using the WRMSL. Discrete $P$-wave velocity, $\mathrm{MAD}$, and thermal conductivity measurements were made on samples from working-half sections. Trends in the physical property data generally correlate with the lithologic units (Figure F11). NGR values are typically low and vary from 46 to 96 counts/s in lithologic Unit II. NGR has slightly reduced variability in lithologic Unit III where values typically vary between 53 and 91 counts/s. MAD porosity values generally decrease with depth; however, variations are observed within Unit III where porosity increases to $30 \%$ at $1386-$ 1423 mbsf and decreases to $25 \%$ below 1423 mbsf. The average grain density is $2.76 \mathrm{~g} / \mathrm{cm}^{3}$. Magnetic susceptibility values downhole show a distinct decrease at the Unit II/III boundary ( 1360 mbsf).

$P$-wave velocity values show a gradually increasing trend with depth with a distinct $\sim 600 \mathrm{~m} / \mathrm{s}$ increase at $\sim 1360$ mbsf. Generally, the $x$ - and $y$-direction values are higher than the $z$-direction values, indicating anisotropy (Figure F11). Thermal conductivity values are similar in Units II and III, ranging from 1.5 to $4.5 \mathrm{~W} /(\mathrm{m} \cdot \mathrm{K})$ with an average of $2.46 \mathrm{~W} /(\mathrm{m} \cdot \mathrm{K})$. The highest values are observed across the Unit II/III boundary.

\section{Downhole measurements}

Because of the concern that the hole would not stay open long enough to conduct multiple logging runs, we decided to deploy a single logging tool string. A modified triple combo tool string was made up with the MSS (magnetic susceptibility), HRLA (resistivity), DSI (sonic), HLDS (caliper only), and the HNGS (spectral gamma ray). The maximum depth reached by the tools was $1494 \mathrm{mbsf}, 6 \mathrm{~m}$ above the bottom of the hole, indicating that only a minimal amount of fill had accumulated. The caliper log shows that the hole was in very good condition below $1345 \mathrm{mbsf}$, the interval with the most complete core recovery. Above 1345 mbsf, the hole size is irregular but does not seem to have significantly affected the quality of the data except for the sonic shear velocity waveforms. Most data agree well with the shipboard physical properties and will allow us to characterize the lithology where recovery was incomplete.

Preliminary interpretation shows that the most significant change in the data recorded occurs at $1360 \mathrm{mbsf}$, the transition between lithologic Units II and III. Below this boundary, all logs become much less variable, as the formation is dominated by claystone. Logging data recorded in the drilled interval below the casing (without core recovery; 734-1150 mbsf) display a character similar to the data recorded within the cored interval of lithologic Unit II (1150-1360 mbsf), suggesting a similar lithology. The alternation of clay/claystone and sand/sandstone intervals in this unit likely controls the overall variability in the logs and the hole size.

\section{Core-log-seismic integration}

Linking core observations to site survey seismic data using downhole logging data at Site U1481 was achieved by generating synthetic seismograms using the $P$-wave sonic log and linking data from a known depth to time on the seismic reflection section. The $P$-wave sonic log provides seismic velocity from which a good timedepth relationship could be obtained in the uncased interval (Figure F11). The method focused on correlation between the cores, logs, and seismic interpretation around seismic Horizon $\mathrm{C}$ and then refinement of tie points using synthetic seismograms, constructed by merging the highest quality sonic log data from the downhole and uphole logging passes. A visual correlation was then carried out against the seismic section by varying the tie time between the two data sets. A high-quality tie point was obtained between the seismic data and synthetic seismograms at Horizon C. The synthetic seismograms give an excellent fit to reflections throughout the seismic section over a time interval more than twice that used during the matching process. This tie and the successful logging suite provides excellent potential for correlation between features from the cores and the regional seismic reflection lines, as well as between reflections and petrophysical/petrological parameters estimated from the $\log$ data.

\section{Preliminary scientific assessment}

The overarching goals of Expedition 362 were to sample, using cores and logs, the sedimentary section and upper basement rocks that comprise the inputs to the North Sumatra subduction zone. Our main objectives were to characterize the lithologic, geochemical, hydrogeological, geomechanical, stress state, and thermal properties of the materials that become incorporated into the thick and broad accretionary prism and that control the location and behavior of the plate boundary décollement fault of the northern Sumatran subduction margin. The original operational plan was to sample the input materials at two locations that provided access to the basement with slightly varying sedimentary thickness. This two-site plan would allow us to assess regional properties and how they may ultimately influence seismogenesis, tsunamigenesis, and forearc development along the Sunda subduction zone.

Because of operational downtime, 11 days of expedition time were lost. In addition, borehole conditions, as predicted, proved challenging for wireline logging. Therefore, the planned coring and logging operations could not be fully completed. In spite of these 
challenges, the expedition was an overwhelming success. At Site U1480, the full stratigraphic section including ocean crust basement was sampled downhole to 1431.6 mbsf (Figures F8, F10). A minimal downhole program was conducted here, consisting of shallow temperature measurements and a simple logging run primarily within the cased interval. At Site U1481, a drilled interval was followed by sampling from 1150 to total depth (TD) of 1500 mbsf, just short of acoustic basement (Figures F9, F11). Good-quality wireline log data (one logging run only) were collected to the bottom of the hole, an impressive achievement considering the materials and the caliper-measured enlarged hole diameter in the middle part of the section. At both sites, adoption of the drill-in casing method undoubtedly enabled reaching target depth in significant water depths ( $>4000 \mathrm{~m}$ ) and penetration depths within challenging materials (i.e., interbedded unconsolidated sands). At both sites, recovery was good, surprisingly so within the sand-rich sections of the Nicobar Fan units. Hole U1481A, with a total penetration depth of 5678 mbsl, constitutes one of the deepest boreholes in scientific ocean drilling.

\section{Meeting the objectives of the expedition}

The fully cored stratigraphic succession between the two sites will enable us to determine links between the depositional and burial history and the developing lithologic, physical, chemical, and mechanical properties of the section. The local variations in lithology downhole and between sites, in particular in the deeper stratigraphic succession below the fan deposits and the range of igneous lithologies, provide an understanding of the heterogeneity of the input succession.

The cored and logged sections provide details of initial consolidation state and level of diagenesis. The successful sampling and logging programs and respective ties to seismic data will enable predictions based on postcruise experimental and numerical modeling of how the materials will evolve under increasing burial conditions and ultimately behave seismogenically and in the building of the major north Sumatran forearc prism. The in situ formation temperature and pressure program could not be fully completed; however, shallow in situ temperature measurements provide important constraints on the initial thermal state of the section as input into models of its evolution as it approaches the subduction zone.

Initial observations of mechanical/strength properties and deformation (both natural and drilling-related) of the input lithologies with depth and their integration with precruise seismic interpretations provide insight into potential localization horizons that may play a role in detachment development, both for plate boundary seismogenesis and prism building. These horizons will be targeted in the postcruise program.

Because of the limited logging program during the expedition, no formation image log data or in situ stress measurements could be collected. Therefore, in situ stress cannot be evaluated at this time. However, core data will be further analyzed and integrated with seismic data analysis to assess both the paleostress and present-day deformation state.

The successful sampling of the complete sedimentary succession will enable us to build a detailed history of the previously undersampled Nicobar Fan and to place it in a context of wider Indian Ocean submarine fan development and regional tectonics and climate.

Below we summarize the preliminary highlights of the scientific achievements of Expedition 362.

\section{Depositional history}

An important objective of the expedition was to establish the depositional history and significance of the Nicobar Fan in recording signals of major tectonic and climatic changes in the EurasianIndian collision zone and Indian Ocean. Sampling of the full sedimentary section at Site U1480 and partial section at Site U1481 enabled identification of principal lithologies, grain compositions, depositional environments, sediment accumulation rates, and diagenetic and lithification state. The observed mineral assemblage of the sediment gravity flow deposits is consistent with a general provenance from Himalayan rivers (e.g., Garzanti et al., 2004), and the succession is interpreted to represent different stages of fan development. The sampled assemblage will enable direct comparison between the Nicobar Fan and records of sedimentation elsewhere in the Bengal and Indus Fans.

The deeper pre-Nicobar Fan succession (Late Cretaceous to Miocene) includes a diversity of abyssal-plain environment hemipelagic, pelagic, tuffaceous, and igneous lithologies, but with variation in thickness and lithologic heterogeneity between the two sites, separated by only a short distance $(\sim 35 \mathrm{~km})$. Extraction of pyritized biosilica alongside calcareous micro/nannofossils, combined with available paleomagnetic measurements, enabled a well-refined agedepth relationship to be developed. This revealed marked changes in sediment accumulation rates between the early pelagic succession (low rates) and overlying submarine fan (very rapid sedimentation, with rates orders of magnitude higher than in the pelagic succession), and several potential hiatuses.

Preliminary analysis of the depositional history of the Nicobar Fan and its implications for Himalayan erosion and the distribution of sediments within the Bengal-Nicobar Submarine Fan during the late Neogene are described in McNeill et al. (2017a). The onset of Nicobar Fan deposition at the drill sites ( 9.5 Ma; Hüpers et al., 2017; McNeill et al., 2017a) is significantly younger than was anticipated precruise ( 30-40 Ma; see Background and objectives in the Site U1480 chapter [McNeill et al., 2017b], based on previous regional analyses of Bengal-Nicobar Fan history and presumptions of gradual fan progradation).

\section{Mechanical properties and deformation of the input section}

Shipboard structural and physical property measurements on cores from Sites U1480 and U1481 provided insights into the consolidation state, strength, and deformation of the input sediments to the North Sumatra subduction margin. Overall, many bulk physical properties change with lithologic unit. Lithologic Unit I is thin and shows a rapid decrease in porosity that correlates with shallow compaction. Through lithologic Unit II and the upper part of Unit III, the rate of porosity loss is slowed, and the rate of porosity loss is lower than observed at other subduction input systems, such as Nankai (Saito, Underwood, Kubo, and the Expedition 322 Scientists, 2010). At Site U1480, two zones of anomalous porosity exist, one indicating undercompaction and one indicating overcompaction. $P$-wave velocity data also display changes near lithologic boundaries. $P$-wave velocity anisotropy increases from near zero (isotropic) in the shallow sediments to transversely anisotropic in the deeper part of lithologic Subunit IIB and below. $P$-wave velocity also shows a marked increase at the Unit II/III boundary. Together, these physical property data suggest increased strength and development of anisotropy, perhaps related to fabric development. Addi- 
tional postcruise research is required to investigate the source of this stiffening and potential fabric development and how it may impact overall strength and potentially localization zones for décollement development.

Structural constraints on mechanical properties focused on identification of natural and induced deformation and analysis of drilling parameters. Most of the sedimentary section had a small number of natural structures (e.g., bedding dips $<5^{\circ}$ ), and zones with increased structural deformation were identified as localization horizons. Four localization horizons were identified based on a combination of abundant localized faulting and effort required to cut the core (coring rate of penetration), determined by drilling parameters. These horizons will be investigated in more detail to better understand the origin of the deformation and how it may relate to strain localization and detachment development as sediments approach the deformation front.

\section{Geochemistry and fluids of the input section}

An extensive pore fluid sampling plan including whole-round and Rhizon sampling helped identify two fluid chemistry anomalies of the sedimentary inputs to the subduction zone. The first is the presence of two phosphate peaks in the upper $150 \mathrm{mbsf}$ at Site U1480; the shallow interval was not cored at Site U1481. Both peaks span $\sim 20$ m intervals: the shallower peak is near the seafloor, and the magnitude is small, controlled by organic matter diagenesis; the second peak is sharp and large and may be controlled by a regional flow system. Similar phosphate peaks were observed in the shallow pore fluids sampled during IODP Expeditions 353 and 354 elsewhere on the Bengal-Nicobar Fan system (Figure F3) (Clemens, Kuhnt, LeVay, and the Expedition 353 Scientists, 2016; France-Lanord, Spiess, Klaus, and the Expedition 354 Scientists, 2016).

The second pore fluid anomaly was observed deeper in the section, within Unit III where pore fluid freshening was observed. The freshening, noted by a very sharp chloride change, suggests it is a recent phenomenon and has not been significantly impacted by diffusion. A preliminary interpretation is that this freshening reflects the first in a series of dehydration reactions, and further progression of these reactions could increase fluid pressures and influence sediment strength and petrophysical properties. Preliminary analysis of this chemical anomaly and implications for the evolution of the input section and plate boundary fault formation and behavior are described by Hüpers et al. (2017). Additional sediment geochemical analyses and modeling work will further constrain the roles of these reactions on freshening and how they evolve with burial. Below the freshening horizon, we also see additional differences between the two sites. Pore water data from the deepest sample collected at Site U1480 show distinct interactions with basement fluids, most notably in calcium, magnesium, and sulfate. Coring at Site U1481 did not reach basement, and the pore fluids at this site do not show influence of basement fluids.

Collectively, the pore water profiles suggest multiple fluid and geochemical processes acting simultaneously at these sites and a complex fluid flow system. As fluids can play an important role in effective stress and strength, we are confident that continued research will provide new insights on the role of fluids in shaping this subduction margin.

\section{Diagenesis}

An important objective of Expedition 362 was to understand the level of diagenesis and how it progresses as the input sediments approach the deformation front. See Geochemistry and fluids of the input section for discussion of geochemical evidence of diagenesisrelated dehydration reactions and their implications for décollement development (Hüpers et al., 2017). The primary diagenetic process at Sites U1480 and U1481 is compaction. Porosity data confirm lithology-dependent compaction trends for mud and sand. The compaction process correlates with unlithified sediments near the seafloor and lithified sediments dominating in Unit III and below. Unit II contains unlithified, partially lithified, and lithified intervals. In addition to the mechanical compaction processes, some isolated intervals with calcite cementation were also observed; primarily as calcite-cemented sandstones but in a few instances as calcite-cemented mudstones. These cemented intervals tend to have low porosity and distinctively high $P$-wave velocity. Although not dominant, these cemented intervals provide some insight into how the sand-rich Nicobar Fan succession may strengthen with further burial and cementation. This strengthening is important for understanding the formation of detachment surfaces and the origin of the broad prism plateau of the Northern Sumatra subduction margin. Additional postcruise work on thermal and diagenetic evolution of the input sediments and reactive transport models on cementation processes will help us constrain when and where these physical properties change, how they impact the overall strength of the system, and how they may be recorded in seismic reflection data.

\section{Basement characterization}

Oceanic basement was sampled at Site U1480 with overlying sediments confirming a Late Cretaceous age. At Site U1481, oceanic basement was not reached, and integration of core, log, and seismic data suggests that both sedimentary and igneous lithologies contribute to the basement seismic reflectivity. At Site U1480, a range of igneous lithologies was cored at the base of the section, including basaltic, often altered, flows; an intermediate composition sill; and oceanic crustal basalt. Volcaniclastic sediments containing volcanic glass and discrete ash layers are an important component within the pelagic succession underlying the submarine fan deposits at both sites. Glass shards include both mafic (likely proximal source) and felsic (likely distal source) compositions and have undergone significant levels of alteration. Glass alteration inevitably contributes to clay composition and potentially to pore water chemistry in the deeper part of the stratigraphic section (Hüpers et al., 2017). The diversity of intrusive and extrusive lithologies may reflect proximity to the NER or more distal volcanic sources. Postcruise research will focus on igneous lithology composition, age, and alteration to determine the evolution of the succession, the provenance of igneous-derived sediments within the succession, and the diagenetic/alteration state of the succession, from emplacement to present-day to future as the succession is buried deeper and reaches higher temperatures.

\section{Seismic integration and regional tectonic setting}

Core $P$-wave velocity and density data, novel drilling parameter analysis of seismic-scale channels within cored intervals, and in particular sonic log data for the entire Site U1481 open-hole section collectively have provided a reliable integration of drilling results with seismic data around the two sites, thus providing a robust time-depth tie and regional correlation of borehole groundtruthed data. Linking drilling results to the site survey seismic data around Sites U1480 and U1481 confirms that the succession of strong subhorizontal reflections accompanied by channel complexes through much of the seismic section represent the Nicobar Fan deposits. Further analysis of the seismic reflection data integrated with the expedition cores and logs (including paleolatitudes from paleo- 
magnetic data) will enable the wider stratigraphic architecture of the fan and underlying section to be developed and placed regionally in the context of northward Indo-Australian plate motion, the wider Bengal-Nicobar Fan system, and impact on input variability along the Sunda subduction zone. The prominent seismic reflector (seismic Horizon C) that develops negative polarity in proximity to the subduction zone is a primary candidate for décollement development (Dean et al., 2010) and marks the boundary (Unit II/III) between the early pelagic sediment and the rapidly deposited Nicobar Fan. This boundary/transition is characterized by distinct changes in degree of lithification, lithology, physical properties (in particular, magnetic susceptibility), and seismic reflectivity and is potentially associated with diagenetic processes generating fluid (see also Hüpers et al., 2017). Differences in the early sedimentary succession between the two sites can be investigated through analysis of paleotopography and proximity to the NER utilizing regional seismic data.

Pervasive normal/transtensional faulting of the input sedimentary section at seismic scale (e.g., Geersen et al., 2015) is not evident as deformation at core scale, indicating that faulting is primarily localized and deformation is not distributed. Where confirmed natural fault structures can be identified within cores, displacement is predominantly normal, including early fault structures, suggesting this style of deformation has dominated the section through time and over a range of spatial scales. Integrating core-log-seismic data indicates that the acoustic basement of the Indian oceanic plate may represent a range of lithologies, from oceanic crustal basalt, to localized sills, to discontinuously cemented sedimentary horizons.

\section{References}

Bangs, N.L., Shipley, T.H., Gulick, S.P.S., Moore, G.F., Kuromoto, S., and Nakamura, Y., 2004. Evolution of the Nankai Trough décollement from the trench into the seismogenic zone: inferences from three-dimensional seismic reflection imaging. Geology, 32(4):273-276. https://doi.org/10.1130/G20211.2

Bletery, Q., Sladen, A., Jiang, J., and Simons, M., 2016. A Bayesian source model for the 2004 great Sumatra-Andaman earthquake. Journal of Geophysical Research: Solid Earth, 121(7):5116-5135. https://doi.org/10.1002/2016JB012911

Briggs, R.W., Sieh, K., Meltzner, A.J., Natawidjaja, D., Galetzka, J., Suwargadi, B., Hsu, Y., Simons, M., Hananto, N., Suprihanto, I., Prayudi, D., Avouac, J.-P., Prawirodirdjo, L., and Bock, Y., 2006. Deformation and slip along the Sunda megathrust in the great 2005 Nias-Simeulue earthquake. Science, 311(5769):1897-1901. http://dx.doi.org/10.1126/science.1122602

Byrne, T., and Hibbard, J., 1987. Landward vergence in accretionary prisms: the role of the backstop and thermal history. Geology, 15(12):1163-1167. https://doi.org/10.1130/0091-

7613(1987)15<1163:LVIAPT >2.0.CO;2

Carton, H., Singh, S.C., Hananto, N.D., Martin, J., Djajadihardja, Y.S., Udrekh, U., Franke, D., and Gaedicke, C., 2014. Deep seismic reflection images of the Wharton Basin oceanic crust and uppermost mantle offshore northern Sumatra: relation with active and past deformation. Journal of Geophysical Research: Solid Earth, 119(1):32-51. http://dx.doi.org/10.1002/2013JB010291

Chester, F.M., Rowe, C., Ujiie, K., Kirkpatrick, J., Regalla, C., Remitti, F., Moore, J.C., Toy, V., Wolfson-Schwehr, M., Bose, S., Kameda, J., Mori, J.J., Brodsky, E.E., Eguchi, N., Toczko, S., and the Expedition 343 and 343T Scientists, 2013. Structure and composition of the plate-boundary slip zone for the 2011 Tohoku-oki Earthquake. Science, 342(6163):1208-1211. https://doi.org/10.1126/science.1243719

Chlieh, M., Avouac, J.-P., Hjorleifsdottir, V., Song, T.-R.A., Ji, C., Sieh, K., Sladen, A., Hebert, H., Prawirodirdjo, L., Bock, Y., and Galetzka, J., 2007. Coseismic slip and afterslip of the great $\left(\mathrm{M}_{\mathrm{w}}\right.$ 9.15) Sumatra-Andaman earthquake of 2004. Bulletin of the Seismological Society of America, 97(1A):S152-S173. http://dx.doi.org/10.1785/0120050631

Clemens, S.C., Kuhnt, W., LeVay, L.J., and the Expedition 353 Scientists, 2016. Indian Monsoon Rainfall. Proceedings of the International Ocean Discovery Program, 353: College Station, TX (International Ocean Discovery Program). https://doi.org/10.14379/iodp.proc.353.2016

Cochran, J.R., 1990. Himalayan uplift, sea level, and the record of Bengal Fan sedimentation at the ODP Leg 116 sites. In Cochran, J.R., Stow, D.A.V., et al., Proceedings of the Ocean Drilling Program, Scientific Results, 116: College Station, TX (Ocean Drilling Program), 397-414. http://dx.doi.org/10.2973/odp.proc.sr.116.144.1990

Cook, B.J., 2014. Along and across strike variations in the structure, material and fault properties of the Sumatran Subduction Zone [Ph.D. thesis]. University of Southampton, United Kingdom. http://ethos.bl.uk/OrderDetails.do?uin=uk.bl.ethos.640761

Cook, B.J., Henstock, T.J., McNeill, L.C., and Bull, J.M., 2014. Controls on spatial and temporal evolution of prism faulting and relationships to plate boundary slip offshore north-central Sumatra. Journal of Geophysical Research: Solid Earth, 119(7):5594-5612. http://dx.doi.org/10.1002/2013JB010834

Curray, J.R., and Moore, D.G., 1974. Sedimentary and tectonic processes in the Bengal deep-sea fan and geosyncline. In Burk, C.A., and Drake, C.L. (Eds.), The Geology of Continental Margins: New York (Springer-Verlag), 617-627.

Curray, J.R., and Moore, D.G., 1982. Growth of the Bengal deep-sea fan and denudation in the Himalayas. Geological Society of America Bulletin, 82(3):563-572. http://dx.doi.org/10.1130/00167606(1971)82[563:GOTBDF]2.0.CO;2

Dahlen, F.A., 1984. Noncohesive critical Coulomb wedges: an exact solution. Journal of Geophysical Research: Solid Earth, 89(B12):10125-10133. http://dx.doi.org/10.1029/JB089iB12p10125

Davis, D., Suppe, J., and Dahlen, F.A., 1983. Mechanics of fold-and-thrust belts and accretionary wedges. Journal of Geophysical Research: Solid Earth, 88(B2):1153-1172. http://dx.doi.org/10.1029/JB088iB02p01153

Dean, S.M., McNeill, L.C., Henstock, T.J., Bull, J.M., Gulick, S.P.S., Austin, J.A., Jr., Bangs, N.L.B., Djajadihardja, Y.S., and Permana, H., 2010. Contrasting décollement and prism properties over the Sumatra 2004-2005 earthquake rupture boundary. Science, 329(5988):207-210. http://dx.doi.org/10.1126/science.1189373

Delescluse, M., Chamot-Rooke, N., Cattin, R., Fleitout, L., Trubienko, O., and Vigny, C., 2012. April 2012 intra-oceanic seismicity off Sumatra boosted by the Banda-Aceh megathrust. Nature, 490(7419):240-245. http://dx.doi.org/10.1038/nature11520

Engdahl, E.R., Villaseñor, A., DeShon, H.R., and Thurber, C.H., 2007. Teleseismic relocation and assessment of seismicity (1918-2005) in the region of the $2004 \mathrm{M}_{\mathrm{w}}$ Sumatra-Andaman and $2005 \mathrm{M}_{\mathrm{w}} 8.6$ Nias Island great earthquakes. Bulletin of the Seismological Society of America, 97(1A):S43-S61. https://doi.org/10.1785/0120050614

Fisher, D., Mosher, D., Austin, J.A., Jr., Gulick, S.P.S., Masterlark, T., and Moran, K., 2007. Active deformation across the Sumatran forearc over the December 2004 $\mathrm{M}_{\mathrm{w}} 9.2$ rupture. Geology, 35(2):99-102. http://dx.doi.org/10.1130/G22993A.1

France-Lanord, C., Derry, L., and Michard, A., 1993. Evolution of the Himalaya since Miocene time: isotopic and sedimentological evidence from the Bengal Fan. In Treloar, P.J., and Searle, M. (Eds.), Himalayan Tectonics. Geological Society Special Publication, 74(1):603-621. http://dx.doi.org/10.1144/GSL.SP.1993.074.01.40

France-Lanord, C., Spiess, V., Klaus, A., Schwenk, T., and the Expedition 354 Scientists, 2016. Bengal Fan. Proceedings of the International Ocean Discovery Program, 354: College Station, TX (International Ocean Discovery Program). https://doi.org/10.14379/iodp.proc.354.2016

France-Lanord, C., Spiess, V., Molnar, P., and Curray, J.R., 2000. Summary on the Bengal Fan: An Introduction to a Drilling Proposal. Woods Hole Oceanographic Institution. http://www.whoi.edu/pclift/BengalSummary.pdf 
Franke, D., Schnabel, M., Ladage, S., Tappin, D.R., Neben, S., Djajadihardja, Y.S., Müller, C., Kopp, H., and Gaedicke, C., 2008. The great SumatraAndaman earthquakes-imaging the boundary between the ruptures of the great 2004 and 2005 earthquakes. Earth and Planetary Science Letters, 269(1-2):118-130. http://dx.doi.org/10.1016/j.epsl.2008.01.047

Frederik, M.C.G., Gulick, S.P.S., Austin, J.A., Jr., Bangs, N.L.B., and Udrekh, 2015. What 2-D multichannel seismic and multibeam bathymetric data tell us about the North Sumatra wedge structure and coseismic response. Tectonics, 34(9):1910-1926. https://doi.org/10.1002/2014TC003614

Fujii, Y., and Satake, K., 2007. Tsunami source of the 2004 Sumatra-Andaman earthquake inferred from tide gauge and satellite data. Bulletin of the Seismological Society of America, 97(1A):S192-S207. http://dx.doi.org/10.1785/0120050613

Fujiwara, T., Kodaira, S., No, T., Kaiho, Y., Takahashi, N., and Kaneda, Y., 2011. The 2011 Tohoku-Oki earthquake: displacement reaching the trench axis. Science, 334(6060):1240. http://dx.doi.org/10.1126/science.1211554

Gaedicke, C., Franke, D., Ladage, S., Tappin, D., Baranov, B., Barckhausen, U., Berglar, K., Delisle, G., Djajadihardja, Y., Heyde, I., Lutz, R., Kafid, K., Mueller, C., Nur Adi, K., Park, J., Seeber, L., Neben, S., and Triarso, E., 2006. Imaging the rupture areas of the giant northern Sumatra earthquakes: a multidisciplinary geophysical experiment. Eos, Transactions American Geophysical Union, 87(52)(Supplement):U52A-01. (Abstract) http://abstractsearch.agu.org/meetings/2006/FM/U52A-01.html

Garzanti, E., Vezzoli, G., Andò, S., France-Lanord, C., Singh, S.K., and Foster, G., 2004. Sand petrology and focused erosion in collision orogens: the Brahmaputra case. Earth and Planetary Science Letters, 220(1-2):157174. http://dx.doi.org/10.1016/S0012-821X(04)00035-4

Geersen, J., Bull, J.M., McNeill, L.C., Henstock, T.J., Gaedicke, C., ChamotRooke, N., and Delescluse, M., 2015. Pervasive deformation of an oceanic plate and relationship to large $>M_{w} 8$ intraplate earthquakes: the northern Wharton Basin, Indian Ocean. Geology, 43(4):359-362. http://dx.doi.org/10.1130/G36446.1

Geersen, J., McNeill, L., Henstock, T.J., and Gaedicke, C., 2013. The 2004 Aceh-Andaman earthquake: early clay dehydration controls shallow seismic rupture. Geochemistry, Geophysics, Geosystems, 14(9):3315-3323. http://dx.doi.org/10.1002/ggge.20193

Gulick, S.P.S., Austin, J.A., Jr., McNeill, L.C., Bangs, N.L.B., Martin, K.M., Henstock, T.J., Bull, J.M., Dean, S., Djajadihardja, Y.S., and Permana, H., 2011. Updip rupture of the 2004 Sumatra earthquake extended by thick indurated sediments. Nature Geoscience, 4(7):453-456. http://dx.doi.org/10.1038/ngeo1176

Gutscher, M.-A., Klaeschen, D., Flueh, E., and Malavieille, J., 2001. Non-coulomb wedges, wrong-way thrusting, and natural hazards in Cascadia. Geology, 29(5):379-382. https://doi.org/10.1130/00917613(2001)029<0379:NCWWWT >2.0.CO;2

Henstock, T.J., McNeill, L.C., and Tappin, D.R., 2006. Seafloor morphology of the Sumatran subduction zone: surface rupture during megathrust earthquakes? Geology, 34(6):485-488. http://dx.doi.org/10.1130/22426.1

Hsu, Y.-J., Simons, M., Avouac, J.-P., Galetzka, J., Sieh, K., Chlieh, M., Natawidjaja, D., Prawirodirdjo, L., and Bock, Y., 2006. Frictional afterslip following the 2005 Nias-Simeulue earthquake, Sumatra. Science, 312(5782):1921-1926. http://dx.doi.org/10.1126/science.1126960

Hüpers, A., Torres, M.E., Owari, S., McNeill, L.C., Dugan, D., Henstock, T.J., Milliken, K.L., Petronotis, K.E., Backman, J., Bourlange, S., Chemale, F., Jr., Chen, W., Colson, T.A., Frederik, M.C.G., Guèrin, G., Hamahashi, M., House, B.M., Jeppson, T.N., Kachovich, S., Kenigsberg, A.R., Kuranaga, M., Kutterolf, S., Mitchison, F.L., Mukoyoshi, H., Nair, N., Pickering, K.T., Pouderoux, H.F.A., Shan, Y., Song, I., Vannucchi, P., Vrolijk, P.J., Yang, T., and Zhao, X., 2017. Release of mineral-bound water prior to subduction tied to shallow seismogenic slip off Sumatra. Science, 356(6340):841-844. https://doi.org/10.1126/science.aal3429

Karig, D.E., Lawrence, M.B., Moore, G.F., and Curray, J.R., 1980. Structural framework of the fore-arc basin, NW Sumatra. Journal of the Geological Society, 137(1):77-91. http://dx.doi.org/10.1144/gsjgs.137.1.0077

Konca, A.O., Avouac, J.-P., Sladen, A., Meltzner, A.J., Sieh, K., Fang, P., Li, Z., Galetzka, J., Genrich, J., Chlieh, M., Natawidjaja, D.H., Bock, Y., Fielding, E.J., Ji, C., and Helmberger, D.V., 2008. Partial rupture of a locked patch of the Sumatra megathrust during the 2007 earthquake sequence. Nature, 456(7222):631-365. http://dx.doi.org/10.1038/nature07572

Kroon, D., Steens, T., and Troelstra, S.R., 1991. Onset of monsoonal related upwelling in the western Arabian Sea as revealed by planktonic foraminifers. In Prell, W.L., Niitsuma, N., et al., Proceedings of the Ocean Drilling Program, Scientific Results, 117: College Station, TX (Ocean Drilling Program), 257-263. http://dx.doi.org/10.2973/odp.proc.sr.117.126.1991

Lay, T., Kanamori, H., Ammon, C.J., Nettles, M., Ward, S.N., Aster, R.C., Beck, S.L., Bilek, S.L., Brudzinski, M.R., Butler, R., DeShon, H.R., Ekström, G., Satake, K., and Sipkin, S., 2005. The great Sumatra-Andaman earthquake of 26 December 2004. Science, 308(5725):1127-1133.

http://dx.doi.org/10.1126/science.1112250

McNeill, L., Dugan, B., and Petronotis, K., 2016. Expedition 362 Scientific Prospectus: The Sumatra Subduction Zone. International Ocean Discovery Program. http://dx.doi.org/10.14379/iodp.sp.362.2016

McNeill, L.C., Dugan, B., Backman, J., Pickering, K.T., Pouderoux, H.F.A., Henstock, T.J., Petronotis, K.E., Carter, A., Chemale, F., Jr., Milliken, K.L., Kutterolf, S., Mukoyoshi, H., Chen, W., Kachovich, S., Mitchison, F.L., Bourlange, S., Colson, T.A., Frederik, M.C.G., Guèrin, G., Hamahashi, M., House, B.M., Hüpers, A., Jeppson, T.N., Kenigsberg, A.R., Kuranaga, M., Nair, N., Owari, S., Shan, Y., Song, I., Torres, M.E., Vannucchi, P., Vrolijk, P.J., Yang, T., Zhao, X., and Thomas, E., 2017a. Understanding Himalayan erosion and the significance of the Nicobar Fan. Earth and Planetary Science Letters, 475:134-142. https://doi.org/10.1016/j.epsl.2017.07.019

McNeill, L.C., Dugan, B., Petronotis, K.E., Backman, J., Bourlange, S., Chemale, F., Chen, W., Colson, T.A., Frederik, M.C.G., Guèrin, G., Hamahashi, M., Henstock, T., House, B.M., Hüpers, A., Jeppson, T.N., Kachovich, S., Kenigsberg, A.R., Kuranaga, M., Kutterolf, S., Milliken, K.L., Mitchison, F.L., Mukoyoshi, H., Nair, N., Owari, S., Pickering, K.T., Pouderoux, H.F.A., Yehua, S., Song, I., Torres, M.E., Vannucchi, P., Vrolijk, P.J., Yang, T., and Zhao, X., 2017b. Site U1480. In McNeill, L.C., Dugan, B., Petronotis, K.E., and the Expedition 362 Scientists, Sumatra Subduction Zone. Proceedings of the International Ocean Discovery Program, 362: College Station, TX (International Ocean Discovery Program). https://doi.org/10.14379/iodp.proc.362.103.2017

McNeill, L.C., and Henstock, T.J., 2014. Forearc structure and morphology along the Sumatra-Andaman subduction zone. Tectonics, 33(2):112-134. https://doi.org/10.1002/2012TC003264

Meltzner, A.J., Sieh, K., Chiang, H.-W., Shen, C.-C., Suwargadi, B.W., Natawidjaja, D.H., Philibosian, B., and Briggs, R.W., 2012. Persistent termini of 2004- and 2005-like ruptures of the Sunda megathrust. Journal of Geophysical Research: Solid Earth, 117(B4):B04405. http://dx.doi.org/10.1029/2011JB008888

Moore, G.F., Curray, J.R., and Emmel, F.J., 1982. Sedimentation in the Sunda Trench and forearc region. Geological Society Special Publication, 10(1):245-258. http://dx.doi.org/10.1144/GSL.SP.1982.010.01.16

Moore, G.F., Curray, J.R., Moore, D.G., and Karig, D.E., 1980. Variations in geologic structure along the Sunda fore arc, northeastern Indian Ocean. In Hayes, D.E. (Ed.), The Tectonic and Geologic Evolution of Southeast Asian Seas and Islands. Geophysical Monograph, 23:145-160. http://dx.doi.org/10.1029/GM023p0145

Moore, J.C., and Saffer, D., 2001. Updip limit of the seismogenic zone beneath the accretionary prism of southwest Japan: an effect of diagenetic to lowgrade metamorphic processes and increasing effective stress. Geology, 29(2):183-186. http://dx.doi.org/10.1130/00917613(2001)029<0183:ULOTSZ>2.0.CO;2

Newman, A.V., Hayes, G., Wei, Y., and Convers, J., 2011. The 25 October 2010 Mentawai tsunami earthquake, from real-time discriminants, finite-fault rupture, and tsunami excitation. Geophysical Research Letters, 38(5):L05302. http://dx.doi.org/10.1029/2010GL046498

Pesicek, J.D., Thurber, C.H., Zhang, H., DeShon, H.R., Engdahl, E.R., and Widiyantoro, S., 2010. Teleseismic double-difference relocation of earthquakes along the Sumatra-Andaman subduction zone using a 3-D model. Journal of Geophysical Research: Solid Earth, 115(B10):B10303. https://doi.org/10.1029/2010JB007443

Pimm, A.C., 1974. Sedimentology and history of the northeastern Indian Ocean from Late Cretaceous to recent. In von der Borch, C.C., Sclater, 
J.G., et al., Initial Results of the Deep Sea Drilling Project, 22: Washington, DC (U.S. Government Printing Office), 717-803. http://dx.doi.org/10.2973/dsdp.proc.22.139.1974

Rhie, J., Dreger, D., Bürgmann, R., and Romanowicz, B., 2007. Slip of the 2004 Sumatra-Andaman earthquake from joint inversion of long-period global seismic waveforms and GPS static offsets. Bulletin of the Seismological Society of America, 97(1A):S115-S127. http://dx.doi.org/10.1785/0120050620

Saffer, D.M., and Bekins, B.A., 2006. An evaluation of factors influencing pore pressure in accretionary complexes: implications for taper angle and wedge mechanics. Journal of Geophysical Research: Solid Earth, 111(B4):B04101. http://dx.doi.org/10.1029/2005JB003990

Saito, S., Underwood, M.B., Kubo, Y., and the Expedition 322 Scientists, 2010. Proceedings of the Integrated Ocean Drilling Program, 322: Tokyo (Integrated Ocean Drilling Program management International, Inc.). http://dx.doi.org/10.2204/iodp.proc.322.2010

Seely, D.R., 1977. The significance of landward vergence and oblique structural trends on trench inner slopes. In Talwani, M., and Pitman, W.C.I. (Eds.), Island Arcs, Deep Sea Trenches, and Back-Arc Basins. Maurice Ewing Series, 1:187-198.

Singh, S.C., Carton, H., Chauhan, A.S., Androvandi, S., Davaille, A., Dyment, J., Cannat, M., and Hananto, N.D., 2010. Extremely thin crust in the Indian Ocean possibly resulting from plume-ridge interaction. Geophysical Journal International, 184(1):29-42. http://dx.doi.org/10.1111/j.1365-246X.2010.04823.x

Singh, S.C., Carton, H., Tapponnier, P., Hananto, N.D., Chauhan, A.P.S., Hartoyo, D., Bayly, M., Moeljopranoto, S., Bunting, T., Christie, P., Lubis, H., and Martin, J., 2008. Seismic evidence for broken oceanic crust in the 2004 Sumatra earthquake epicentral region. Nature Geoscience, 1(11):777-781. http://dx.doi.org/10.1038/ngeo336

Smith, G., McNeill., L., Henstock, T.J., and Bull, J., 2012. The structure and fault activity of the Makran accretionary prism. Journal of Geophysical Research: Solid Earth, 117(B7):B07407. http://dx.doi.org/10.1029/2012JB009312

Smith, G.L., McNeill, L.C., Wang, K., He, J., and Henstock, T.J., 2013. Thermal structure and megathrust seismogenic potential of the Makran subduction zone. Geophysical Research Letters, 40(8):1528-1533.

http://dx.doi.org/10.1002/grl.50374
Song, T.-R.A., and Simons, M., 2003. Large trench-parallel gravity variations predict seismogenic behavior in subduction zones. Science, 301(5633):630-633. http://dx.doi.org/10.1126/science.1085557

Spinelli, G.A., Mozley, P.S., Tobin, H.J., Underwood, M.B., Hoffman, N.W., and Bellew, G.M., 2007. Diagenesis, sediment strength, and pore collapse in sediment approaching the Nankai Trough subduction zone. Geological Society of America Bulletin, 119(3-4):377-390. http://dx.doi.org/10.1130/B25920.1

Tilmann, F.J., Craig, T.J., Grevemeyer, I., Suwargadi, B., Kopp, H., and Flueh, E., 2010. The updip seismic/aseismic transition of the Sumatra megathrust illuminated by aftershocks of the 2004 Aceh-Andaman and 2005 Nias events. Geophysical Journal International, 181(3):1261-1274. https://doi.org/10.1111/j.1365-246X.2010.04597.x

Underwood, M.B., 2007. Sediment inputs to subduction zones: why lithostratigraphy and clay mineralogy matter. In Dixon, T., and Moore, J.C. (Eds.), The Seismogenic Zone of Subduction Thrust Faults: New York (Columbia University Press), 42-85.

Vann, I.R., Graham, R.H., and Hayward, A.B., 1986. The structure of mountain fronts. Journal of Structural Geology, 8(3-4):215-227. http://dx.doi.org/10.1016/0191-8141(86)90044-1

von der Borch, C.C., Sclater, J.G., et al., 1974. Initial Reports of the Deep Sea Drilling Project, 22: Washington (U.S. Government Printing Office). http://dx.doi.org/10.2973/dsdp.proc.22.1974

Wang, K., and Hu, Y., 2006. Accretionary prisms in subduction earthquake cycles: the theory of dynamic Coulomb wedge. Journal of Geophysical Research: Solid Earth, 111(B6):B06410. http://dx.doi.org/10.1029/2005JB004094

Wei, S., Helmberger, D., and Avouac, J.-P., 2013. Modeling the 2012 Wharton Basin earthquakes off-Sumatra: complete lithospheric failure. Journal of Geophysical Research: Solid Earth, 118(7):3592-3609. http://dx.doi.org/10.1002/jgrb.50267

Wells, R.E., Blakely, R.J., Sugiyama, Y., Scholl, D.W., and Dinterman, P.A., 2003. Basin-centered asperities in great subduction zone earthquakes: a link between slip, subsidence, and subduction erosion? Journal of Geophysical Research: Solid Earth, 108(B10):2507. http://dx.doi.org/10.1029/2002JB002072 